\title{
THE FUTURE OF CONSTITUTIONALLY REQUIRED LESSER INCLUDED OFFENSES
}

\author{
Michael H. Hoffheimer ${ }^{*}$
}

Where is the philosopher who will deny that two men in two neighboring departments may commit the same crime, and one will lose his head, and the other, and perhaps the worse villain of the two, keeps his upon his shoulders? We must have equality in life, forsooth, and we have inequality in the administration of the law, and in the penalty of death. ${ }^{1}$

\section{INTRODUCTION}

For over a generation courts have recognized that failing to instruct juries on lesser included offenses results in wrongful convictions. ${ }^{2}$ In Beck $v$. Alabama, ${ }^{3}$ the Supreme Court held that in capital cases juries must be instructed on the option of returning convictions of non-capital lesser included offenses. The Court explained that this right prevents juries from being forced to make all-or-nothing choices between guilt and innocence in cases where

* Professor of Law and Mississippi Defense Lawyers Association Distinguished Lecturer, University of Mississippi School of Law. J.D. University of Michigan Law School 1984; Ph.D. University of Chicago 1981; B.A. The Johns Hopkins University 1977.

I am very grateful to Professors Joshua Dressler, Jack Wade Nowlin, Larry J. Pittman, Michael Vitiello and Lloyd L. Weinreb for helpful critical suggestions on drafts of this Article. The author received a grant from the National Center for Justice and the Rule of Law, which is supported by Grant No. 2000-DD-VX-0032 awarded by the Bureau of Justice Assistance. The Bureau of Justice Assistance is a component of the Office of Justice Programs, which includes the Bureau of Justice Statistics, the National Institute of Justice, the Office of Juvenile Justice and Delinquency Prevention and the Office of Victims of Crime. Points of view or opinions in this Article are those of the author and do not represent the official position of the United States Department of Justice.

1. Honoré de Balzac, The Peasantry, in 12 The Works of Honoré de Balzac 144-45 (Harper \& Brothers Publishers 1900) (1844).

2. The Supreme Court of Ohio explained in 1965:

[I]f evidence tending to prove a lesser included offense is present and a jury is inhibited by the charge from finding defendant guilty thereof, the collective conscience of that body may too easily be disposed to fabricate the elements of the crime charged in the indictment and to find defendant guilty as charged rather than risk, by a verdict of acquittal, turning the malefactor loose upon a society grievously harmed by his act. State v. Loudermill, 206 N.E.2d 198, 200 (Ohio 1965).

3. 447 U.S. 625 (1980); see infra Part III. 
serious crimes have been committed and pressures to convict of some crime are great. $^{4}$

Beck demonstrated that the Supreme Court would not defer to state law regarding whether lesser included offense instructions should be given because Alabama's refusal to give instructions in that case did not prevent the Court from reversing. But the Court subsequently held that state law governs the issue of whether lesser included offenses exist to the crime charged. ${ }^{5}$ The Court has repeatedly emphasized that lesser included offense instructions need be given only when supported by the evidence, ${ }^{6}$ but the Court has never explained whose evidence law governs in determining whether lesser included offense instructions are constitutionally required.

This Article maintains that the most pressing constitutional issue regarding lesser included offense instructions in capital cases is whether federal or state law governs the measure of evidence required for the instructions. State prosecutors and judges have powerful incentives both for resisting defense requests for lesser included offense instructions and for justifying the refusal to give such instructions on the ground that they are not warranted by the evidence. ${ }^{8}$ Accordingly, to secure Beck's goal of reducing the risk of wrongful convictions in capital cases resulting from all-or-nothing pressures to convict, the Supreme Court must adopt minimum federal standards governing the evidence necessary for such instructions.

Part II surveys the policies served by lesser included offenses. It concludes that evidentiary requirements for lesser included offense instructions result from judicial concern that jury compromise may erode accurate factfinding. Part III examines Supreme Court decisions clarifying the

4. Beck, 447 U.S. at 637-38; see also Schad v. Arizona, 501 U.S. 624, 646 (1991) (emphasizing that the Court's "fundamental concern in Beck was that a jury convinced that the defendant had committed some violent crime but not convinced that he was guilty of a capital crime might nonetheless vote for a capital conviction if the only alternative was to set the defendant free with no punishment at all"); Spaziano v. Florida, 468 U.S. 447, 455 (1984) (observing that " [t] $]$ he absence of a lesser inclu ded offense instruction increases the risk that the jury will convict ... simply to avoid setting the defendant free").

5. Hopkins v. Reeves, 524 U.S. 88 (1998); see infra Part IV.

6. Beck, 447 U.S. at 627 (quoting the question presented as being whether lesser included offense instructions must be given in a capital case "when the evidence would have supported such a verdict"); see also Hopper v. Evans, 456 U.S. 605, 611 (1982).

7. Jurisdictions differ regarding the evidentiary requirements for instructing on lesser included offenses. The majority of states require lesser included offense instructions only when supported by some evidence but they differ regarding the measure of evidence necessary to entitle a defendant to such instructions. A small group of states permits lesser included offense instructions regardless of the evidence. See infra text accompanying notes 205-12.

8. See infra Part V.B.2. 
scope of the constitutional right to lesser included offense instructions. It links these decisions to the Burger Court's commitment to protecting the rights of innocent defendants and to the Court's historic concern with regulating jury decision-making in death penalty cases.

Part IV considers the Court's deference to state definitions of lesser included offenses in Hopkins $v$. Reeves. ${ }^{9}$ It argues that, although the holding in Hopkins comports with the core values of Beck, Justice Thomas's reliance on federalist values signaled a retreat from Beck's goal of reducing erroneous factfinding. Part V then addresses the need for the Supreme Court to clarify whether Beck permits deference to state rules regarding the evidence necessary for lesser included offense instructions. It discusses the missed opportunity for judicial clarification presented by Howell v. Mississippi. ${ }^{10}$ It shows how that case illustrates the tendency of states to justify denials of requests for lesser included offense instructions on evidentiary grounds, and it explores the record in that case as an example of the difficulty in determining when such instructions are warranted.

Part VI confronts federalism issues raised by the conflict between the constitutional mandate of lesser included offense instructions in capital cases and the Court's respect for state control over rules governing lesser included offenses. It argues that the constitutional requirement of lesser included offense instructions promotes mutual federal and state interests in preventing wrongful capital convictions. Moreover, the constitutional restriction of such instructions to cases where there is evidentiary support for the lesser included offense promotes the interest in reducing the risk of improper jury compromise that is shared by most (but not all) state courts. Nevertheless, this Article maintains that the Supreme Court must adopt an independent constitutional standard to assure that states do not evade the constitutional obligation to give lesser included offense instructions in appropriate cases. It specifically proposes that the Court should adopt the minimal evidentiary test standard currently employed by federal trial courts for determining when to give lesser offense instructions. This minimal test will accommodate legitimate state interests in reducing erroneous factfinding and will assure that state and federal trial courts apply the same rule in reaching capital

9. 524 U.S. 88 .

10. 125 S. Ct. 856,858 (2005) (dismissing the writ of certiorari as improvidently granted in a case where the defendant, convicted of capital murder, argued in state appellate courts that the trial court's failure to instruct on murder and manslaughter violated state law, but "did not properly present his claim as one arising under federal law"). 
convictions when that rule is specifically designed to reduce wrongful convictions.

\section{Overview of Lesser Included Offenses}

\section{A. The Two-Part Test: Summary of the Confusion}

American courts inherited the common law practice of permitting juries to acquit defendants of a felony charged in an indictment and to convict of certain less serious crimes that were committed during the charged offense and necessarily included in the indictment. ${ }^{11}$ Some sources conclude from the history that lesser included offenses emerged as a convenience for prosecutors. ${ }^{12}$ But at common law, decisions about jury instructions were made by trial judges in consultation with prosecuting attorneys for the simple reason that criminal defendants were not represented by counsel. ${ }^{13}$ In any event, by the end of the nineteenth century, American courts recognized that defendants had a right to request lesser included offense instructions in appropriate cases..$^{14}$

Significantly different legal issues are presented by cases where lesser included offense charges are presented in addition to the greater charge. A few states require instruction on all applicable lesser included offenses. ${ }^{15}$ But federal courts and most states require lesser included offense instructions only

11. See generally Michael H. Hoffheimer, The Rise and Fall of Lesser Included Offenses, 36 Rutgers L.J.351, 374 (2005) (discussing the history of lesser included offenses). For the Supreme Court's history of the doctrine, see Keeble v. United States, 412 U.S. 205, 208 (1973). Keeble's historical account has been repeated by commentators, e.g., Deanna Hall, Note, The "Third Option": Extending the Lesser Included Offense Doctrine to the Non-Capital Context, 29 Hofstra L. Rev. 1333, 1335-36 (2001), and was relied on by the Court in Beck v. Alabama, 447 U.S. 625, 635 n. 11 (1980).

12. This historical view was adopted by the Supreme Court. See Beck, 447 U.S. at 633 ("This rule [permitting conviction of a lesser included offense] originally developed as an aid to the prosecution in cases in which the proof failed to establish some element of the crime charged." (citing 2 CHARLES Alan Wright, Federal Practice and Procedure $\$ 515$ n.54 (1969))).

13. The legal right to counsel in felony prosecutions was not recognized in England until 1836. J.H. Baker, An Introduction to English Legal History 583 (3d ed. 1990). The right to counsel was set forth in the Bill of Rights, U.S. ConsT. amend. VI ("In all criminal prosecutions, the accused shall enjoy the right to ... have the Assistance of Counsel for his defence."), but it has been deemed a fundamental right binding on the states only since 1963, Gideon v. Wainwright, 372 U.S. 335 (1963).

14. E.g., Stevenson v. United States, 162 U.S. 313 (1896).

15. See infra text accompanying notes 205-12. Even in these states, however, a defendant must usually request instructions and, even when requested, the failure to give instructions may be harmless error when proof of the charged offense is overwhelming. 
in cases where they are supported by the record. ${ }^{16}$ Accordingly, courts in most jurisdictions must resolve two different issues. First, they must decide whether a formal charge contains lesser included offenses. Second, they must decide whether lesser included offense instructions are required under the facts of the case. The first inquiry deals with the legal definition of lesser included offenses. The second deals with when lesser included offense instructions should be given.

The simplicity of the two-part test hides significant anomalies that cumulatively raise doubts about how accurately the test really explains the outcome of cases. In general, the first part of the test is underinclusive: more instructions are required than meet the test. The second is overinclusive: fewer cases actually require instructions than would seem to meet the test. The first is underinclusive because states require instruction on some lesser offenses that do not satisfy the definition of lesser included offenses. ${ }^{17}$ In addition, the Constitution requires instruction on lesser included offenses that may not meet a state's criteria. ${ }^{18}$ The second test is overinclusive because trial courts do not apply it consistently and appellate courts do not require its consistent application. ${ }^{19}$

It is tempting to characterize the first inquiry as one of law and the second as one of fact. ${ }^{20}$ This would be misleading, though, because both determinations are questions of law — or mixed questions of law and fact — in the sense that they are made by trial judges rather than juries. Appellate courts appear more reluctant to reverse decisions denying lesser included

16. See infra text accompanying notes 216-18. The Supreme Court held that lesser included offense instructions are required only when supported by evidence in Beck, 447 U.S. 625, and Hopper v. Evans, 456 U.S. 605 (1982), but it evidently assumed that all jurisdictions imposed a similar evidentiary requirement.

17. Courts sometimes find these lesser related offenses to be distinct from lesser included offenses. See James A. Shellenberger \& James A. Strazzella, The Lesser Included Offense Doctrine and the Constitution: The Development of Due Process and Double Jeopardy Remedies, 79 MARQ. L. REv. 1, 13 (1995) (explaining the difference between lesser included offenses and lesser related offenses). See generally Russell G. Donaldson, Annotation, Lesser-Related State Offense Instructions: Modern Status, 50 A.L.R. 4th 1081 (1986 and Supp. 2005) (compiling state cases recognizing a right to lesser related offense instructions).

18. E.g., Beck, 447 U.S. 625.

19. For an example of a case where a state trial court's refusal to apply the second test is cursorily approved by the appellate courts, see Part V (discussing Howell v. Mississippi, 125 S. Ct. 856 (2005)).

20. The question of whether a charged felony comprises lesser included offenses is in theory a matter of analysis of formal definitions under the so-called evidence test now adopted by most states, see Hoffheimer, supra note 11, at 411-23. But other states still consider the fact-specific context of the prosecution's theory of the case. There is substantial case law and scholarly literature discussing the variety of judicial definitions of lesser included offenses, see id. 
offense instructions based on the sufficiency of evidence than to reverse decisions based on conclusions that requested instructions do meet definitions of lesser included offenses. But this reluctance does not stem from a policy of according deference to trial court decision-making on matters of fact. ${ }^{21}$

On the contrary, appellate courts explain that lesser included offense instructions must be given when there is a factual dispute about the elements that distinguish the greater and lesser offenses. ${ }^{22}$ Although trial court familiarity with the factual record traditionally justifies substantial deference to trial court decisions regulating evidence, familiarity with the record does not dictate the standard of review of decisions about jury instructions. Deference is not appropriate where the reviewing court is not required to evaluate the weight or effect of evidence but is required merely to determine whether the record establishes the existence of a fact dispute that must be submitted to the jury. ${ }^{23}$ In making such a determination, appellate courts caution trial judges not to evaluate the weight or credibility of evidence in deciding whether a dispute exists. ${ }^{24}$

21. No appellate court appears to have openly adopted an abuse-of-discretion standard of review for such decisions.

22. E.g., Keeble v. United States, 412 U.S. 205, 208 (1973) (stating the federal rule that a defendant is entitled to a lesser included offense instruction where the evidence would permit the jury rationally to find the defendant guilty of the lesser, and not guilty of the greater, offense); Sansone v. United States, 380 U.S. 343,349 (1965) (stating that a lesser included offense instruction is not proper where there is no factual dispute on elements that distinguish the greater and lesser offenses).

23. In Young v. United States, 309 F.2d 662 (D.C. Cir. 1962), the defendant was charged with assault with intent to commit robbery. The defendant testified that he searched the victim's pockets merely for weapons. The trial court refused to instruct on simple assault, and the defendant was convicted. The District of Columbia Circuit reversed. Judge Burger acknowledged that the evidence of simple assault was not strong or convincing and its source was of dubious reliability, "but the question of its weight and credibility was for the jury. ... The ruling denying the lesser included offense instruction necessarily involved an appraisal of that evidence and [of the witness's] credibility by the District Judge but the trier cannot withdraw that appraisal from the jury." Young, 309 F.2d at 663.

24. Many opinions state the rule that trial judges should give lesser included offense instructions when there is a dispute about the elements that distinguish the greater and lesser offenses and caution trial courts not to withhold such instructions because of their judgment as to the weight of the evidence on the matter in dispute. See Broughman v. United States, 361 F.2d 71 (D.C. Cir. 1966) (reversing a robbery conviction where the defendant testified that he was defending a third person and the trial court refused to instruct on simple assault, and observing that the defendant's testimony provided fact questions for the jury); United States v. Kuefler, 14 C.M.A. 136, 139 (C.M.A. 1963) (reversing a housebreaking conviction where the defendant denied he entered with intent to steal but admitted larceny, and observing that "[a]ccused's story may be implausible; it may have been rejected by the fact finders; and, indeed, it may, in light of the other evidence, smack of an afterthought by which he sought to escape his just deserts. But neither [the appellate nor the trial court] has the right so to pass upon accused's credibility."); Tucker v. United States, 871 A.2d 453, 461 (D.C. 2005) ("Any evidence, however weak, is sufficient to support a lesser-included instruction so long as a jury could rationally convict . . . after crediting the evidence." 
Courts agree in theory that lesser included offense instructions should be given when a real dispute exists about either a factual circumstance or a state of mind that distinguishes the greater and lesser included offenses. For example, where the weight of contraband is disputed, it is reversible error to fail to instruct on a less serious offense that is defined by possession of the lower quantity. ${ }^{25}$ Likewise, it is reversible error in a prosecution for attempted capital murder to fail to instruct on the crime of aggravated assault when the record establishes a real dispute as to whether the defendant had the specific intent to kill that distinguishes the greater from the lesser included offense. ${ }^{26}$

The presence of sufficient evidence to support a conviction of the greater offense should never by itself prevent instruction on lesser included offenses. Charges supported by insufficient evidence should obviously not be submitted to the jury, and convictions supported by insufficient evidence should be reversed; therefore, lesser included offense instructions provide defendants no additional safeguards against wrongful convictions in such cases. In other

(quoting Woodard v. United States, 738 A.2d 254, 261 (D.C. 1999))); Louisy v. State, 667 So. 2d 972, 974 (Fla. Dist. Ct. App. 1996) ("Even if the weight of the evidence is overwhelmingly in favor of the state's charge, the defendant is entitled to an instruction on a lesser offense as to which there is any evidence." (quoting Kolaric v. State, 616 So. 2d 117, 119 (Fla. Dist. Ct. App. 1993))); Boyd v. State, 557 So. 2d 1178 , 1182 (Miss. 1989) ("Only if this Court can say, taking the evidence in the light most favorable to the accused, and considering all reasonable favorable inferences which may be drawn in favor of the accused from the evidence, and considering that the jury may not be required to believe any evidence offered by the state, that no hypothetical reasonable jury could convict [of the lesser included offense], can it be said that the refusal of a lesser included offense instruction was proper." (quoting Ruffin v. State, 444 So. 2d 839, 840 (Miss. 1984))); State v. Givens, 917 S.W.2d 215, 219 (Mo. Ct. App. 1996) ("The trial court should resolve all doubts upon the evidence in favor of instructing on the lower degree of the crime, leaving it to the jury to decide of which of the two offenses, if any, the defendant is guilty."); State v. Young, 669 P.2d 239, 242 (Mont. 1983) (reversing a felony theft conviction where the trial court refused to instruct on misdemeanor theft, and observing that, "[e]ven though the [trial court] here may have considered the evidence ... weak and inconclusive, it was still bound to in struct the jury on the lesser-included offense of misdemeanor theft, since the weight to be given to the evidence is a question for the jury"); State v. Loudermill, 206 N.E.2d 198, 201 (Ohio 1965) ("The jury should not be denied its right to pass upon the credibility and weight of the evidence by failing to charge a lesser included offense where there is evidence tending to support a charge of a lesser included offense."); State v. Parsons, 247 N.E.2d 482, 484 (Ohio Ct. App. 1969) (reversing a robbery conviction where the trial court refused to instruct on assault and battery, and observing that "any evidence from which any reasonable inference may be drawn to support an included offense requires a charge covering that offense"); Hayes v. State, 728 S.W.2d 804, 809 (Tex. Crim. App. 1987) ("It is well established that if evidence from any source raises the issue of a lesser included offense... it must be included in the court's charge." (citation omitted)); Gibson v. State, 726 S.W.2d 129 (Tex. Crim. App. 1987) ("It is not the court's function to determine the credibility or weight to be given the evidence raising the defensive issue or lesser included offense.").

25. E.g., Givens, 917 S.W.2d 215; People v. Smith, 619 N.Y.S.2d 87 (N.Y. App. Div. 1994).

26. See Sanchez v. State, 745 S.W.2d 353, 356 (Tex. Crim. App. 1988) ("We find that a jury could find, but would not be required to find, from the favorable admitted evidence that appellant was only guilty of committing the offense of aggravated assault ...."). 
words, defendants need lesser included offense instructions only in cases where there is already sufficient evidence of the greater offense. ${ }^{27}$ Sufficient evidence of guilt of the greater offense should never render the omission to instruct on lesser included offenses harmless error. ${ }^{28}$

Difficulties abound in connection with the question of what evidence is needed to create a real dispute entitling a defendant to lesser included offense instructions. For the majority of jurisdictions, the mere burden of proof on additional elements does not create such a real dispute. ${ }^{29}$ These jurisdictions require the presence of some evidence that supports a finding that the lesser offense may have been committed but not the greater. But these jurisdictions vary in their descriptions of the kind of evidence necessary to require submission of the lesser offense charge to the jury. ${ }^{30}$

Even when lesser included offense instructions may be available, trial courts (encouraged by prosecutors) frequently resist defense requests for instructions on lesser included offenses. The number of appeals in all states indicates that trial courts do not err on the side of giving such instructions, and appellate courts have occasionally expressed exasperation with the refusal of

27. Cf. Givens, 917 S.W.2d at 218 n.1 (emphasizing that the fact that the State made a submissible case for the greater offense does not resolve the question of whether there was a basis for acquittal of that offense and conviction of a lesser included offense).

28. This is not to deny that numerous appellate decisions employ harmless error to affirm where the trial court failed to instruct on lesser included offenses. For example, in Burgess v. Galaza, No. 99-15459, 2000 U.S. App. LEXIS 4082 (9th Cir. Mar. 13, 2000), the court denied habeas corpus relief to a prisoner convicted of murder and attempted robbery who claimed that failure to instruct on the larceny charge violated due process. The court observed that the failure to instruct was "harmless because there was sufficient evidence for the jury to find [defendant] guilty of attempted robbery beyond reasonable doubt." $I d$. at *5. But the record in Burgess indicates sound alternative grounds for affirming. First, defense counsel never requested lesser included offense instructions, opting instead for an all-or-nothing strategy. Second, evidence of intent to use force was so overwhelming that the court of appeals could have concluded beyond a reasonable doubt that the instruction, even if requested, would not have affected the verdict.

29. The State bears the burden of proofbeyond a reasonable doubt on all elements, including those that distinguish the greater offense. If this additional burden were enough to create an evidentiary dispute, then defendants would always be entitled to lesser included offense instructions, regardless of the specific facts in the record. But only a small minority of states recognize an absolute right to instruction on lesser included offenses. See infra text accompanying notes 205-12. For similar reasons, the right of the jury to disbelieve all evidence, including evidence on the additional elements needed to prove the greater offense, will not by itself create a dispute entitling a defendant to lesser included offense instructions. See Skinner v. State, 956 S.W.2d 532, 543 (Tex. Crim. App. 1997) ("It is not enough that the jury may disbelieve crucial evidence pertaining to the greater offense."); cf. Givens, 917 S.W.2d at $218 \mathrm{n} .1$ (observing a division of opinion over whether disbelief of testimony by itself provides a rational basis for acquitting of a greater and convicting of a lesser included offense).

30. See infra Part VI.B.1. 
trial courts to abide by appellate standards encouraging lesser included offense instructions. $^{31}$

This Article proposes that much of the legal confusion about the circumstances that require lesser included offense instructions stems from the context in which courts must apply the second part of the test. Courts determine whether there are sufficient facts to require lesser included offenses exclusively in criminal prosecutions where the question is whether to empower the jury to select among two or more different crimes, all of which are supported by sufficient evidence. ${ }^{32}$ The decision of whether to permit juries to engage in this selection raises important policy issues because the power of selection includes the power to compromise.

\section{B. The First Part: Defining Lesser Included Offenses}

States generally agree in characterizing lesser included offenses as crimes "necessarily included" in a greater crime, but they differ in how they define such lesser included offenses. ${ }^{33}$ Some apply definitions that require a determination of whether less serious crimes were actually committed at the time the charged offense occurred. These jurisdictions would conclude that the crime of discharging a weapon within city limits was a lesser included offense of murder when a defendant was charged with intentionally killing a victim in a city with a gun. ${ }^{34}$ Other states and the federal government employ the elements test, which determines whether all elements of a less serious crime are included as a subset of the elements of the more serious crime. These jurisdictions would conclude that the crime of discharging a gun in a city is not a lesser included offense of murder because the elements of murder do not include the elements of the lesser crime.

31. E.g., Boyd v. State, 557 So. 2d 1178, 1181 (Miss. 1989) ("For some unknown reason, our competent and able trial judges continue to refuse instructions on lesser included offenses when the evidence warrants them.").

32. In contrast, courts routinely apply the first part of the test, the definition of lesser included offense, in procedural contexts that require no jury election. For example, a trial court may permit a defendant to be prosecuted solely for a lesser included offense of a crime charged in the indictment, or it may permit the jury to find liability of a lesser included offense after it has acquitted of a greater offense. Similarly, trial or appellate courts may direct entry of judgment of a lesser included offense when a jury has found a defendant guilty of a greater offense but when the reviewing court concludes that proof is inadequate on some element that distinguishes the greater from the lesser included offense.

33. See generally Hoffheimer, supra note 11, at 411-23; Shellenberger \& Strazzella, supra note 17, at 6-8.

34. I borrowed and modified the example from Shellenberger \& Strazzella, supra note 17, at 10. 


\section{The Second Part: The Requirement of Supporting Evidence}

Lesser included offense instructions serve a variety of interests. They provide procedural economies that benefit all parties by reducing costs and delays that would result if the prosecution was required to obtain new indictments for lesser crimes supported by the evidence. They permit appellate courts to reverse convictions unsupported by evidence while affirming or even entering judgments of lesser offenses abundantly proven on the record..$^{35}$ These procedural economies are achieved whether the jury is instructed only on a lesser included offense or is given the option of convicting of either the charged offense or the lesser included offense.

In contrast, giving juries the option of convicting of either greater or lesser included offenses raises new issues that relate to the perceived benefits of jury compromise. In Anglo-American jurisdictions, juries serve both as institutions that bring community values into the process of legal decisionmaking and as the finders of disputed facts. Any legal device that expands the decision-making opportunities of the jury-including opportunities to compromise or to disregard legal rules - will expand the power of juries to implement community norms in individual cases. Accordingly, the juries' role in infusing popular values into the legal process is enlarged by giving juries the power to compromise in all cases. At the same time, legal devices that permit compromise do so at the cost of undermining the factual accuracy of jury decision-making.

Two different classes of cases illustrate this tension. In cases where evidence of murder is weak but defendants are otherwise unsympathetic, juries may compromise by acquitting of murder but convicting of manslaughter. Conversely, in cases where the evidence of murder is strong but the defendants are sympathetic, juries may compromise by convicting of the lesser crime of manslaughter. Such compromise is not troubling-indeed it is desirable - where there is ample evidence of either crime or where the jury's factfinding responsibility extends to evaluating the appropriate level of criminal liability. The criminal law often invites juries to make value judgments by directing them to find facts like "malice."

But defendants may be sympathetic or unsympathetic for reasons unrelated to the level of the offense. For example, where the defendant obviously exhibited a blameworthy mental state in trying to kill the victim, but

35. Such a practice does not violate the double jeopardy clause. Morris v. Mathews, 475 U.S. 237, 246-47 (1986). 
the evidence that the defendant actually caused the victim's death is weak or sharply contested, a jury may be reluctant to convict of murder and may compromise by convicting of manslaughter. ${ }^{36}$

The rules regulating lesser included offense instructions can be best understood as the result of judicial efforts to prevent jury compromise in those contexts where it erodes the accuracy of factfinding. Joshua Dressler maintains that "truth-reliable trial outcomes, in which the guilty are convicted and the innocent are acquitted - is a critical goal of the criminal justice system. ${ }^{n 7}$ The value of truth or accuracy can be frustrated by lesser included offense instructions because compromise verdicts may result in underconvictions of the guilty and overconvictions of the innocent. Juries may compromise by finding defendants who are truly guilty of murder guilty only of a lesser included offense. ${ }^{38}$ Conversely, juries may compromise by convicting a truly innocent defendant of a lesser offense.

Dressler explains that the principle of truth or factual accuracy is hedged in controversy. First, he notes that it remains controversial whether erroneous acquittals and erroneous convictions are equally harmful. ${ }^{39}$ Second, he notes that the value of truth-finding may be subordinated to other values. ${ }^{40}$

The value of factual accuracy may be served by restricting jury options of convicting of different offenses, but this value subsists in tension with the desire to defer to juror decision-making, which is served by submitting alternative offenses to the jury. Because it is settled law in almost every

36. It is probably impossible to prove in any case that juries compromised on the lesser included offense for this reason. But cases disclose that juries will convict a defendant of homicide based on evidence of intent to kill even in the absence of sufficient evidence the defendant caused the victim's death. E.g., People v. Dlugash, 363 N.E.2d 1155 (N.Y. 1977) (reversing a murder conviction due to insufficient evidence that the defendant caused the victim's death, but directing entry of judgment of the lesser included offense of attempted murder).

37. Joshua Dressler, Understanding Criminal Procedure $\S 2.03$, at 29 (3d ed. 2002).

38. Conviction of the lesser offense constitutes an acquittal of the greater.

39. DressLER, supra note $37, \S 2.03$, at 29-30. The common law traditionally maintained that it was better to acquit the guilty than convict the innocent. See generally 4 William Blackstone, COMMENTARIES ON THE LAWS OF ENGLAND *358 (1765) (remarking that "it is better that ten guilty persons escape than that one innocent suffer"). The preference for avoiding punishing the innocent has Biblical authority. Genesis 18:23-32 (recounting dialog between Abraham and the Lord, where the Lord agreed not to destroy Sodom if the town contained ten righteous people). See generally Alexander Volokh, $n$ Guilty Men, 146 U. PA. L. REV. 173 (1997) (compiling efforts to quantify the reluctance to convict).

Dressler's citations evidence the rise of conservative academic arguments that challenged the traditional preference for avoiding wrongful convictions. DRESSLER, supra note 37, at 30-31 nn.29-32. These authors preceded the implementation of current U.S. policy under which select prisoners are held indefinitely without proof of guilt or, indeed, any charge.

40. DressLer, supra note 37, at 31 . 
American jurisdiction that juries have no right to disregard the law, ${ }^{41}$ there is no independent value to be served by permitting juries to convict improperly of lesser included offenses when such convictions are not factually accurate.

The ambivalent commitment to the principle of factual accuracy explains many aspects of the law of lesser included offenses-but not all. For example, it explains why most jurisdictions will not permit jury compromise where evidence of manslaughter is no stronger than for murder. The rule followed by the majority of jurisdictions is that in order for lesser included offense instructions to be given, the evidence must permit a reasonable jury to both convict of the lesser offense and acquit of the greater. ${ }^{42}$ The reasons behind this rule seem obvious, though courts rarely articulate them. The rule advances the policy that discretion regarding the appropriate level of offense be lodged exclusively in prosecutors. Where prosecutors elect to charge a more serious offense and the incriminating evidence for that offense is comparable to that for lesser offenses, most courts will deny juries the opportunity to consider lesser included offenses, forcing them to decide whether the prosecution has proven the serious crime charged. This benefits prosecutors and defendants alike in assuring that legitimate reluctance to

41. Juries have enjoyed the power to disregard the law to the extent that since Bushell's Case, (1670) 124 Eng. Rep. 1006 (C.P.), jury members are immune from punishment if they disregard instructions. See generally BAKER, supra note 13, at 590-91 (discussing the history of "pious perjury," the merciful disregard of law by jurors by means of returning a partial verdict); THOMAS ANDREW GREEN, VERDICT Accordingto Conscience: Perspectiveson the English Criminal Trial Jury 1200-1800, at 200-64 (1985) (discussing the history of Bushell's Case). For over a century American courts have refused to recognize this immunity as the source of a positive right. See generally JoshuA DRessLer, Understanding CRiminal LAW $\S 1.02$, at 5-7 (3d ed. 2001) (discussing the history of the idea of jury nullification).

Today most jurisdictions restrict the power of the jury to decide questions of fact. Indiana and Maryland are unusual in prescribing that juries serve as judges of both fact and law. See InD. Const. art. $1 \S 19$; MD. Declaration of Rights art. 23. But even those states take steps to prevent jurors from disregarding instructions that accurately describe the law. See Holden v. State, 788 N.E.2d 1253, 1255 (Ind. 2003) (reaffirming state judicial policy of refusing to instruct jurors of their right to disregard the law); Rector v. State, 826 N.E.2d 12 (Ind. Ct. App. 2005) (affirming a conviction where a juror was removed for distributing a book advocating jury nullification to other jurors); Thomas v. State, 349 A.2d 384, 388-89 (Md. Ct. Spec. App. 1975) (affirming a conviction where the defendant was prevented from arguing that the jury should acquit due to the severity of the sentence based on the court's conclusion that the jury had no right to disregard the law).

42. For the Supreme Court's version of this rule, see Sansone v. United States, 380 U.S. 343, 349 (1965) (“[A] lesser-offense charge is not proper where, on the evidence presented, the factual issues to be resolved by the jury are the same as to both the lesser and greater offenses. ... A lesser-included offense instruction is only proper where the charged greater offense requires the jury to find a disputed factual element which is not required for conviction of the lesser-included offense." (citations omitted)). See 5 Wayne R. LaFave et AL., Criminal Procedure § 24.8(f), at 587 n.96 (2d ed. 1999) (discussing federal rule). 
convict results in complete acquittal and is not discounted by compromise on a lesser offense that is supported by no more adequate proof.

States differ in how they regulate undesirable jury compromise on lesser included offenses. A few states legislatively proscribe lesser offense instructions for certain types of crimes, ${ }^{43}$ presumably because their legislatures perceive that jury reluctance to convict of certain offenses creates an unacceptable risk of undesirable jury compromise in all prosecutions of that offense. $^{44}$

Most states respect party autonomy and require that either the prosecutor or defendant request lesser included offense instructions. This will promote rational jury compromise only to the extent that parties do not seek to prevent juries from considering appropriate lesser included offenses or that parties do not seek to benefit from irrational jury compromise. Scholars who question whether parties' choices are guided by values of enhancing rational decisionmaking have proposed eliminating the requirement that parties must demand lesser included offense instruction. ${ }^{45}$

While the desire to regulate jury compromise may explain why some judicial decisions withhold instruction on lesser included offenses,${ }^{46}$ there are other sources of judicial resistance to lesser included offense instructions that

43. E.g., New York created new crimes of third-degree rape and third-degree criminal sexual act but prescribed that such crimes would not qualify as lesser included offenses of rape and criminal sexual act. N.Y. CRIM. Proc. LaW $\S 300.50$ (McKinney Supp. 2005). The legislative purpose was to permit prosecution of greater offenses without requiring the submission of charges on lesser offenses without the prosecutor's approval.

44. Alabama courts construed state legislation so as to prevent lesser included offense instruction in all capital prosecutions. It is problematic, however, whether the Alabama statute meant to implement such a legislative policy. The Supreme Court squarely held that, regardless of its purpose, such a prohibition was unconstitutional as applied to death penalty cases. See infra Part III.C.

45. See Hoffheimer, supra note 11, at 360 n.20 (discussing cases and scholarship addressing the issue of whether courts should give lesser included offense instructions in the absence of a party request).

46. It is often unclear why states refuse to instruct on lesser included offenses. For example, it is unclear why Nebraska did not include manslaughter as a lesser included offense of felony murder despite the fact that manslaughter might appear to satisfy the general criteria of a lesser included offense. In Hopkins v. Reeves, the defendant argued that the state's policy was arbitrary because it was based on a conclusory characterization, but the Court did not consider that argument because it had not been raised before the lower courts. Hopkins v. Reeves, 524 U.S. 88, 100-01 (1998). In Beck v. Alabama, the State of Alabama argued that its policy of forcing juries to make all-or-nothing choices in capital cases tended to reduce the risk of wrongful conviction by removing the opportunity for compromise (though it apparently did not argue that that was the purpose of the legislative prohibition of lesser included offense instructions in capital cases). Brief of Respondent at 10-13, Beck v. Alabama, 447 U.S. 625 (1980) (No. 78 -6621). The Court rejected that argument. See Beck v. Alabama, 447 U.S. 625, 638-39, 641-42 (1980) (observing that the State's "theory ... is supported by nothing more than speculation" and contradicted by the 96 percent conviction rate in capital cases). 
may affect the definition of what qualifies as a lesser included offense. For example, the elements test has gained considerable support over the past generation. ${ }^{47}$ While some courts purport to prefer the test because of its simplicity and ease of application, ${ }^{48}$ the elements test restricts the number of crimes that qualify as lesser included offenses, thus reducing the opportunities for jury compromise. ${ }^{49}$

\section{The Constitutional Requirement of Lesser Included Offenses in Capital Cases}

\section{A. Jurisprudence of Actual Innocence}

The Beck opinion displays the rhetoric of factual innocence that dominated the Burger Court's approach to constitutional limits on criminal procedure. In the $1980 \mathrm{~s}$, scholars debated whether such rhetoric covered an authoritarian pro-confinement program that was no less utilitarian than the Warren Court's social reform agenda. ${ }^{50}$ Beck's future is closely bound up with the evolution of the Court's concern with constitutional safeguards protecting the actually innocent. If these concerns are merely pretexts for proconfinement policies, as critics have charged, then they will no doubt yield to state practices that achieve overconvictions. If these concerns express good faith efforts to establish rules binding on states to prevent practices known to pose risks of wrongful conviction, the Court will be prepared to insist on the enforcement of such rules in the face of incompatible state practices.

47. The elements test is now employed by federal courts and a bare majority of states. Hoffheimer, supra note 11, at 406-07, 411-23.

48. E.g., Schmuck v. United States, 489 U.S. 705, 720-21 (1989) (claiming that the elements test is preferable because of its ease of application and promotion of greater certainty); People v. Mendoza, 664 N.W.2d 685, 698 (Mich. 2003) (Cavanagh, J., concurring) (identifying ease-of-application as the rationale for the majority's adoption of the elements test).

49. Of course, by excluding crimes from the definition of lesser included offense, the elements test prevents both prosecutors and defendants from asking for such instructions.

50. Compare Peter Arenella, Rethinking the Functions of Criminal Procedure: The Warren and Burger Courts' Competing Ideologies, 72 GEO. L.J. 185, 192 (1983) (arguing that "[a]t a rhetorical level, the Burger Court consistently criticized procedural safeguards erected by the Warren Court that frustrated the system's capacity to determine factual guilt efficiently, quickly, and conclusively" and that the Burger Court's decisions manifested a consistent commitment to a crime-control model that differed from the Warren Court's policies), with Louis Michael Seidman, Factual Guilt and the Burger Court: An Examination of Continuity and Change in Criminal Procedure, 80 Colum. L. Rev. 436, 437-38 (1980) (criticizing the substantial variation between the Court's decisions and the view of critics who credit the Court with returning the criminal justice system to guilt-based adjudication). 


\section{B. The Issues before the Court in Beck}

The defendant in Beck was convicted of capital murder in a jury trial in Alabama state court. According to the State's evidence, Beck and an accomplice intentionally killed an eighty-year-old victim during the course of a robbery. Beck testified that he participated in the robbery, but he claimed his accomplice unexpectedly caused the victim's death and that he himself had no intent to kill the victim. ${ }^{51}$

A key fact in dispute was Beck's intent, and Beck requested felony murder instructions. Such instructions would have permitted the jury to convict Beck of this less serious form of murder in the event jurors could not agree that Beck intended to kill. But Alabama state practice rules prevented instruction on noncapital homicide crimes when the defendant was charged with the capital crime of robbery during an intentional killing. At Beck's trial, the jury was even informed that if they acquitted Beck of the charged offense he would be discharged and could "never be tried for anything that he ever did to [the victim]." ${ }^{52}$ Faced with this choice, the jury convicted the defendant and sentenced him to death. ${ }^{53}$

Under Alabama law at the time, the capital crime of intentionally killing during robbery required proof of an actual intent to kill, and this intent could not be established by invoking the felony murder rule. ${ }^{54}$ Alabama also had a noncapital form of felony murder, and the Supreme Court observed that "[f]elony murder is thus a lesser included offense of the capital crime of robbery-intentional killing." ${ }_{55}$ The Court did not explain why felony murder was a lesser included offense of robbery-intentional killing.

At the time of the Beck decision, federal courts applied a variety of definitions of lesser included offenses. Alabama's felony murder test under

51. Beck, 447 U.S. at 629-30 ("Under [Beck's] version of the events, he and an accomplice entered their victim's home in the afternoon, and, after [Beck] had seized the man intending to bind him with a robe, his accomplice unexpectedly struck and killed him. As the State has conceded, absent the statutory prohibition on such instructions, this testimony would have entitled [Beck] to a lesser included offense instruction on felony murder as a matter of state law.").

52. Id. at 630 (quoting the trial record).

53. Id. at 627 n.1 (quoting ALA. CODE § 13-11-2(a)(2) (1975) ("Robbery or attempts thereof when the victim is intentionally killed by the defendant[.]")).

54. Id. at $628 \mathrm{n} .2$ (quoting ALA. CODE $\S 13-11-2$ (b) (1975) (stating that "[evidence] of intent ... shall not be supplied by the felony-murder doctrine")); Ex parte Ritter, 375 So. 2d 270, 275 (Ala. 1979) (holding that the State could not prove intent to kill by showing intent to commit robbery or knowledge of substantial possibility that someone would be killed).

55. Beck, 447 U.S. at 628. 
the facts in Beck would have satisfied all the definitions. ${ }^{56}$ In the 1930s, Blockburger v. United States ${ }^{57}$ had applied the so-called elements test to determine whether a defendant could be separately punished for two offenses consistent with the Double Jeopardy Clause. But for nearly a decade after $B e c k$, federal courts continued to apply different tests to determine when a defendant was entitled to lesser included offense instructions at trial. Only in 1989 did the Court resolve the split among the circuits and adopt the elements test for federal trial courts. ${ }^{58}$

What was certain, however, was that the Court did not look to Alabama's practice for guidance, because the Alabama courts enforced the Alabama legislature's prohibition on giving noncapital felony murder instructions in a capital murder trial. ${ }^{59}$ In other words, though the federal definition of lesser included offenses was in a process of evolution, the Supreme Court did not look to the state to determine whether a crime was a lesser included offense, and no one on the Court saw anything paradoxical in the conclusion that felony murder was a lesser included offense of robbery-intentional killing even though state law prohibited giving the felony murder instruction in a prosecution for the greater offense.

The defendant appealed through the state courts, arguing that the state practice of prohibiting relevant lesser included offense instructions amounted to a mandatory death penalty regime. ${ }^{60}$ Before the Supreme Court the defendant argued that prohibiting lesser included offense instructions on the

56. See Hoffheimer, supra note 11, at 406-07. Noncapital murder satisfied the elements test for a lesser included offense of the form of capital murder prosecuted in Beck because the statutory elements of the greater crime included the elements of the lesser included offense: capital murder's elements of intentionally killing during a robbery included noncapital murder's elements of intentionally killing. Noncapital murder also satisfied the evidence test of capital murder, because the evidence needed to convict the defendant necessarily established guilt for murder.

57. 284 U.S. 299, 304 (1932) ("[T]he test to be applied to determine whether there are two offenses or only one, is whether each provision requires proof of a fact which the other does not.").

58. Schmuck v. United States, 489 U.S. 705, $721-22$ (1989) (holding that odometer tampering was not a lesser included offense of mail fraud because it contained an additional element).

59. The Alabama death statute provided that aggravating offenses "shall not include any lesser offenses," and state courts had construed this language to prohibit the submission of lesser included offenses to juries. Beck, 447 U.S. at 628 \& n.3 (citing Ala. CODE § 13-11-2(a) (1975)); Jacobs v. State, 361 So. 2d 640, 646 (Ala. 1978) (Torbert, C.J., concurring in part and dissenting in part), cert. denied, 439 U.S. 1122 (1979); Evans v. Birtton, 472 F. Supp. 707, 714 (S.D. Ala. 1979).

60. Mandatory death penalty regimes are unconstitutional. Woodson v. North Carolina, 428 U.S. 280, 305 (1976); Roberts v. Louisiana, 428 U.S. 325, 336 (1976). 
noncapital crime violated the Eighth Amendment ${ }^{61}$ and the Due Process Clause $^{62}$ by increasing the risk of error.

Alabama did not argue that felony murder was not a lesser included offense because it was not available under state law. Nor did it argue that federal courts should defer to state procedure. Instead, the State justified forcing the all-or-nothing choice on Alabama juries because it fully protected defendants from erroneous jury factfinding. The State maintained that prohibiting lesser included offense instructions assured that juries' doubts resulted in acquittals rather than in compromise verdicts on lesser offenses. ${ }^{63}$ It also insisted that the danger of all-or-nothing pressure to convict was avoided by the power of juries to refuse to return verdicts. Finally, the State argued that any danger of error was reduced by the role of the trial judge in reviewing aggravating and mitigating circumstances. ${ }^{64}$

\section{The Holding and its Rationale}

The Supreme Court reversed the judgment of the Alabama Supreme Court and held that Alabama could not constitutionally impose the death penalty. Justice Stevens wrote a broad opinion that garnered the support of all justices who reached the substantive issues. ${ }^{65}$

The Court began by noting the common law practice under which juries were permitted to find defendants guilty of "any lesser offense necessarily included in the offense charged." ${ }^{.66}$ While this practice may have originated as a convenience for the prosecution, the Court noted that it had also "long

61. U.S. ConSt. amend. VIII (“[N]or [shall] cruel and unusual punishments [be] inflicted.”). Defendant also raised an equal protection issue, U.S. Const. amend. XIV, $§ 1$ ("[N]or shall any State ... deny to any person within its jurisdiction the equal protection of the laws."), based on Alabama's refusal to give lesser included offense instructions only in capital cases, but the Court did not address this issue because it was not raised below. Beck, 447 U.S. at 632 n.8.

62. U.S. Const. amend. XIV, $\S 1$ ("“ [N]or shall any State deprive any person of life, liberty, or property, without due process of law ....").

63. See Beck, 447 U.S. at 633.

64. Id.

65. Justices Rehnquist and White dissented on the ground that the issues before the Court, though properly raised at trial and before the intermediary appellate court, had not been presented to the Supreme Court of Alabama; accordingly, the dissent concluded that the Supreme Court lacked subject matter jurisdiction. Id. at 647-48 (Rehnquist \& White, JJ., dissenting).

Justices Marshall and Brennan concurred in the opinion of the Court but wrote separately to express their opinions that capital punishment per se violated the Constitution. Id. at 646 (Brennan, J., concurring and Marshall, J., concurring).

66. Id. at 633 (majority opinion). 
been recognized" as a benefit to defendants because it presented juries with an alternative to convicting of a more serious offense. ${ }^{67}$

The Court emphasized the nearly universal authority for the practice. Federal courts and all states that considered the issue held that defendants were entitled to lesser included offense instructions when warranted by the evidence, and Alabama itself permitted such instructions in noncapital cases. ${ }^{68}$ Moreover, Alabama's refusal to give lesser included offense instructions in capital cases was idiosyncratic - "unique in American criminal law."

Emphasizing the particular facts and posture of Beck, the Court refrained from finding a general due process right to lesser included offense instructions but observed nevertheless:

[T] he nearly universal acceptance of the rule in both state and federal courts establishes the value to the defendant of this procedural safeguard. That safeguard would seem to be especially important in a case such as this. For when the evidence unquestionably establishes that the defendant is guilty of a serious, violent offense-but leaves some doubt with respect to an element that would justify conviction of a capital offense- the failure to give the jury the "third option" of convicting of a lesser included offense would seem inevitably to enhance the risk of an unwarranted conviction.

Such a risk cannot be tolerated in a case in which the defendant's life is at stake. ${ }^{70}$

The Court emphasized that the special nature of capital cases made the enhanced risk of erroneous conviction unacceptable but did not decide whether the Due Process Clause required such instructions in a noncapital case. $^{71}$

The Court devoted considerable energy to responding to Alabama's arguments that the state practice of prohibiting noncapital lesser offense instructions advanced legitimate criminological policies. It rejected as speculative the State's contention that the all-or-nothing choice enhanced accurate jury deliberations. ${ }^{72}$ It was not persuaded that juries would

67. Id. at 633-35 (quoting Keeble v. United States, 412 U.S. 205, 208 (1973)).

68. Id. at $630 \mathrm{n} .5,635-36 \mathrm{nn} .11-12$.

69. Id. at $635 \&$ n. 10 .

70. Id. at 637 .

71. Id. at 638 \& n.14. Defendant also raised an equal-protection issue based on Alabama's refusal to give lesser included offense instructions only in capital cases, but the Court did not address this issue because it was not raised below. $I d$. at $632 \mathrm{n} .8$.

72. Id. at 638-41. The State argued that historical evidence of high acquittal rates tended to show that juries in mandatory capital punishment regimes would err on the side of acquittal. But Alabama relied on data compiled in Woodson v. North Carolina, 428 U.S. 280, 293 (1976), where the Court concluded that "mandatory" death penalty regimes did not avoid arbitrary results. Moreover, the Court noted that Alabama's conviction rate (96 percent) did not evidence a similar reluctance to convict. Beck, 447 U.S. at 641 . 
sufficiently understand their power to refuse to reach a verdict so as to provide a substitute for proper lesser included offense instructions. ${ }^{73}$ Finally, the Court rejected the argument that the state trial judge's ultimate responsibility for sentencing provided sufficient safeguards against the harmful results of erroneous jury convictions. ${ }^{74}$

\section{Clarification of Beck's Scope}

The Supreme Court clarified the scope of $B e c k^{75}$ in a series of decisions in which it found that the central purpose of lesser included offense instructions, reducing the risk of erroneous factfinding, would not be advanced or would be frustrated by such instructions. In these decisions the Court restated its commitment to Beck's principle while holding that lesser included offense instructions were not constitutionally required when they did not reduce the risk of erroneous factfinding.

\section{Lesser Offenses Inconsistent with Defendant's Theory of the Case}

In Beck the Court had remarked that lesser included offense instructions would be required only when supported by the evidence. ${ }^{76}$ Two years later, in Hopper v. Evans,${ }^{77}$ the Court considered the argument that lesser included offense instructions must be given even when the defendant does not dispute the evidence of the greater inclusive offense. The Court concluded unanimously that a lesser included offense instruction was not required under such circumstances. ${ }^{78}$

73. Beck, 447 U.S. at $644-45$. Arguments and instructions were confusing and inconsistent with respect to the consequences of mistrial. Id. at 644 .

74. The Court articulated four reasons why the judicial hearing was not a sufficient safeguard. First, a trial judge would not have the power to impose a death sentence if a properly instructed jury acquitted. Second, a jury's advisory sentence could motivate a judge to impose the same sentence the jury did. Third, the sentencing rates in Alabama indicated that sentencing judges in fact imposed the death penalty in the vast majority of cases where juries convicted and voted for death. Fourth, there was some evidence that trial judges were under pressure to sentence to death. Id. at 645-46.

75. Scholars have repeatedly called attention to the uncertain implications of Beck. See Shellenberger \& Strazzella, supra note 17, at 17 ("[T] he scope and implications of the Beck decision are unclear. It is not clear, for example, whether a capital defendant is constitutionally entitled to instructions for only one noncapital [lesser included offense], or for the most rational [lesser included offense] in view of the defense theory, or for all [such instructions] warranted by the evidence."); see also Hall, supra note 11 , at $1340-50$.

76. Beck, 447 U.S. at 627.

77. 456 U.S. 605 (1982).

78. Id. at 613. Justices Brennan and Marshall dissented with respect to the sentence, but they joined 
The defendant in Hopper shot a victim in the back during a robbery and was prosecuted in Alabama for the capital crime of intentionally killing during robbery. ${ }^{79}$ This was the same crime that the defendant was charged with in Beck and for which Alabama law prevented lesser included offense instructions.

But while the defendant in Beck denied he intended to kill and requested lesser included offense instructions, the defendant in Hopper bragged about killing the victim, requested no lesser included offense instructions and asked the jury to convict and sentence him to death: "I'm asking very sincerely that you come back with a positive verdict for the State." ${ }^{\prime 80}$ The jury obliged, finding the defendant guilty of capital murder, and he was sentenced to death.

Because the conviction and sentence resulted from the Alabama procedure that the Court held to be unconstitutional in Beck, the defendant later challenged his conviction, arguing that lesser included offense instructions should have been given. ${ }^{81}$ Writing for the Court, Chief Justice Burger reaffirmed Beck's requirement of lesser included offense instructions in capital cases when such instructions reduce the risk of error, but he emphasized that "due process requires that a lesser included offense instruction be given only when the evidence warrants such an instruction." 82

Under the facts of Hopper, a jury instruction for a form of homicide that was warranted only when a defendant lacked intent ${ }^{83}$ would not have reduced the risk of error because the defendant conceded he had intent. Therefore, the Court concluded that the instruction was not constitutionally required.

Hopper was a remarkable case in that its holding could have been justified in a number of different ways. First, the defendant arguably waived the right to jury instruction by failing to request the instructions. Second, the

the majority opinion to the extent that it reversed the appellate decision reversing the conviction. Id. at 614 (Brennan \& Marshall, JJ., concurring in part and dissenting in part).

79. Id. at 606-07. Inculpatory evidence included physical evidence, eyewitnesses, multiple admissions by the defendant, and defendant's testimony. Id. at 606-08.

80. Id. at 608 .

81. Although the defendant evidently did not request lesser included offense instructions, see id. (stating that the defendant changed his attitude of seeking execution only when his mother commenced post-conviction proceedings), the Court did not rely on that failure in its decision. Failure to request instructions would probably be a sufficient ground for reversal under normal principles, as well as under dictum in later cases. See Spaziano v. Florida, 468 U.S. 447, 456-57 (1984) (recognizing that the defendant would prefer not to have the jury given lesser included offense instructions and opining that the defendant could avoid such instruction by refusing to waive the statute of limitations).

82. Hopper, 456 U.S. at 611.

83. The defendant conceded that a conviction of noncapital felony murder was warranted under Alabama law only when a defendant lacked intent to kill. Id. at 613 . 
omission of the instruction was probably harmless error in a case where the defendant admitted being guilty of the greater offense and asked the jury to convict him of it. ${ }^{84}$

Hopper established that the omission of jury instructions should not be grounds for reversal even in a capital case unless the omission somehow prejudiced the defendant. ${ }^{85}$ But the decision still more broadly confirmed the bedrock principles that defendants are not automatically entitled to a lesser included offense instruction, that courts may determine as a matter of law what charges must be submitted to a jury, and that accurate factfinding is not promoted by merciful compromises unsupported by evidence. ${ }^{86}$

Although Hopper was an easy case, and the Chief Justice spoke for a unified Court, the Court's conclusion that the lesser included offense instructions were not warranted conceals an ambiguity that would resurface. The result in Hopper reveals the Court's assumption that it is possible to determine that an instruction is not warranted even when the reason the state court assigns is invalid. Yet the decision does not clearly indicate the legal source for determining whether such instruction is unwarranted. The Chief Justice observed that lesser included offense instructions were required under Alabama case law when there was a reasonable theory that would support conviction of the offense. ${ }^{87}$ But it was not the rule of Alabama case law but rather the statutory prohibition invalidated by Beck that would have motivated the trial court to refuse a request for a lesser included offense instruction if the defendant had requested such instruction (which he did not). The Chief Justice also noted that federal courts require lesser included offense instruction when the evidence would permit a jury rationally to convict of the lesser and acquit of the greater offenses. ${ }^{88}$

The Chief Justice recognized that the impact of state rules would have to be measured against federal constitutional standards, concluding: "The Alabama rule clearly does not offend federal constitutional standards, and no

84. The fact that Beck held that lesser included offense instructions were constitutionally required in other cases where they reduced the risk of erroneous factfinding did not make its omission harmful in the defendant's case.

85. The Chief Justice remarked that the defendant "suggests no plausible claim which he might conceivably have made, had there been no preclusion clause [prohibiting lesser included offense instructions in capital cases], that is not contradicted by his own testimony at trial. The preclusion clause did not prejudice [the defendant] in any way, and a new trial is not warranted." Hopper, 456 U.S. at 613-14.

86. See Sparf v. United States, 156 U.S. 51, 63-64 (1895).

87. Hopper, 456 U.S. at 611 (citing Fulghum v. State, 277 So. 2d 886, 890 (Ala. 1973)).

88. Id. at 612 (citing Keeble v. United States, 412 U.S. 205, 208 (1973)). 
reason has been advanced why it should not apply in capital cases." ${ }^{\text {"99 }}$ But the opinion leaves little doubt that the Court was concerned with requiring lesser included offense instructions only when they would improve the accuracy of jury factfinding. As Beck made clear, state judgments, whether legislative or judicial, regarding the propriety of lesser included offense instructions would be accorded little respect when the Court independently concluded that the state practice actually increased the risk of error by forcing all-or-nothing choices on factfinders.

\section{Alternative Instructions Reducing All-or-Nothing Pressure to Convict}

In Schad v. Arizona,${ }^{90}$ a defendant was charged with both first-degree murder and second-degree murder for killing an elderly driver and stealing his camper. The defendant, caught driving the camper, argued that he might have participated in a robbery but was not guilty of either form of homicide. He was charged with first- and second-degree murder, convicted of first-degree murder and sentenced to death. ${ }^{91}$ The Court rejected the defendant's argument that Beck required that the jury be given the option of convicting of robbery and theft in order to avoid the risk of erroneous factfinding. ${ }^{92}$

The majority emphasized the Court's historical concern with avoiding allor-nothing pressures to convict or acquit of a capital crime, concluding that Beck's requirement of a "third option" of convicting of a noncapital offense was fully satisfied by the alternative second-degree murder charge. The Court wrote, "We repeatedly stressed the all-or-nothing nature of the decision with which the jury was presented. . . This central concern of Beck simply is not implicated in the present case, for petitioner's jury was not faced with an allor-nothing choice between the offense of conviction (capital murder) and innocence. ${ }^{, 93}$

\section{Id.}

90. 501 U.S. 624 (1991).

91. The jury instructions permitted the jury to convict of first-degree murder even if some jurors found that the defendant caused death with premeditation while others found that the defendant caused death without intent during the commission of robbery. The Court concluded that lack of jury unanimity did not offend due process. Id. at 630,649. Four members of the Court agreed on one reason, id. at 627 , 630-45 (Souter, Rehnquist, O’Connor \& Kennedy, JJ., plurality opinion), and Justice Scalia concurred for different reasons, $i d$. at 648-52 (Scalia, J., concurring in part and concurring in the judgment). See generally Elizabeth R. Carty, Note, Schad v. Arizona: Jury Unanimity on Trial, 42 CATH. U. L. Rev. 355, 355-88 (1993) (criticizing the case's treatment of the issue ofjury unanimity as to the theory of conviction).

92. Schad, 501 U.S. at 645-48.

93. Id. at 646-47. 
Justice Souter observed that the evidence was sufficient to support a finding of second-degree murder. ${ }^{94}$ He pointed out that the jury was not forced to vote for a capital conviction or to acquit. To the extent that the denial of a non-homicide option created any pressure to convict, there was no reason to assume there was greater pressure to convict of the capital crime. ${ }^{95}$ Four members of the Court dissented, reasoning that where the state prosecutes alternative theories of a crime, Beck's requirement of a noncapital third option must be satisfied for each crime charged. ${ }^{96}$

\section{Lesser Included Offenses Barred by Statutes of Limitations}

In Spaziano v. Florida,${ }^{97}$ the defendant was convicted of first-degree murder and sentenced to death for the torture murder of a woman. ${ }^{98}$ Although the statute of limitations barred lesser homicide charges, the trial judge offered to instruct the jury on noncapital offenses of first-degree murder, seconddegree murder, third-degree murder, and manslaughter, provided that the defendant would waive statute of limitations defenses to those crimes. ${ }^{99}$ When the defendant refused to waive limitations defenses, the trial court instructed the jury on capital murder. The jury convicted, and the defendant was sentenced to death.

94. Id. at 648 .

95. Id. at 647-48 (stating that, to accept defendant's argument, "we would have to assume that a jury unconvinced that [defendant] was guilty of either capital or second-degree murder, but loath to acquit him completely (because it was convinced he was guilty of robbery), might choose capital murder rather than second-degree murder as its means of keeping him off the streets. Because we can see no basis to assume such irrationality, we are satisfied that the second-degree murder instruction in this case sufficed to ensure the verdict's reliability").

96. Id. at 662 (White, Marshall, Blackmun \& Stevens, JJ., dissenting); see also Michael G. Pattillo, Note, When "Lesser" is More: The Case for Reviving the Constitutional Right to a Lesser Included Offense, 77 Tex. L. Rev. 429, 446 (1998) ("Schad v. Arizona represents another blow to criminal defendants by complying with the letter of Beck while ultimately violating its spirit.").

97. 468 U.S. 447 (1984).

98. Id. at 450 . Though convicted and sentenced on one count of first-degree murder, evidence indicated that the defendant killed two women. The facts are set forth in Spaziano v. State, 393 So. 2d 1119, 1120 (Fla. 1981).

A majority of the jury recommended life imprisonment, but the trial judge sentenced the defendant to death. Spaziano, 468 U.S. at 451-52. The Court found that this procedure was not unconstitutional. Id. at 464-65. Three justices dissented, observing that Florida judges had sentenced defendants to death in eighty-three cases where juries had voted for life imprisonment. Id. at 467 (Stevens, Brennan \& Marshall, JJ., dissenting).

99. Spaziano, 468 U.S. at 450. As in Hopper, it is unclear from the Court's opinion whether the defendant requested lesser included offense instructions. See supra note 81. 
Justice Blackmun characterized the issue: "The issue here is whether the defendant is entitled to the benefit of both the lesser included offense instruction and an expired period of limitations on those offenses." Court unanimously found there was no constitutional error in the failure to give lesser included offense instructions under these facts. ${ }^{101}$ Justice Blackmun especially wanted to avoid giving the defendant strategic advantages that would accrue if defendants could force the jury to elect between two charges, one of which was in fact invalid.

The trial history in Spaziano confirmed Justice Blackmun's concern. Because of perceived weaknesses in the prosecution's case, the jury was reluctant to convict. ${ }^{102}$ In such a case, either the prosecution or the defendant could normally request lesser included offense instructions, but a defendant might calculate that he or she would benefit from the omission of lesser included offense instructions, forcing a reluctant jury to acquit outright. The chief disincentive of requesting lesser included offense instructions would be the threat of conviction of the lesser offense. Where the statute of limitations barred the prosecution from seeking a conviction of the lesser included offense, Justice Blackmun was unwilling to find that the Constitution forced the defendant to waive such valid limitations defenses. A defendant might benefit from forcing an all-or-nothing choice on the jury, and the Court found no injustice in a conviction resulting from such a defense strategy. ${ }^{103}$ While the Beck rule was designed to eliminate the risk of juror error caused by the all-or-nothing pressure to convict, the rule was not designed to eliminate a defendant's deliberate decision to force juries to make such a choice in the hopes of a complete acquittal. ${ }^{104}$

100. Spaziano, 468 U.S. at 454.

101. Id. at 457. Three justices dissented from the Court's previous denial of a writ of certiorari, finding that the constitutional issue was substantial. Spaziano v. Florida, 454 U.S. 1037, 1040 (1982) (Marshall \& Brennan, JJ., dissenting from denial of certiorari) (noting that a "strong argument can be made that the jury should be instructed as to that [lesser included] offense"); id. at 1041 (Blackmun, J., dissenting). Nevertheless, when the Court later granted certiorari and decided the issue on the merits, all three justices agreed that denying instructions under the circumstances was not unconstitutional. Justice Blackmun delivered the opinion of the Court, and Justices Marshall and Brennan agreed with Part II of the Court's opinion treating the lesser included offense issue. Spaziano, 468 U.S. at 490 (Stevens, Brennan \& Marshall, JJ., concurring in part and dissenting in part).

102. The jury was deadlocked and returned a conviction only after receiving an Allen charge. Spaziano, 468 U.S. at $450-51 \&$ n.2. The weakness in the prosecution's case apparently stemmed from the credibility of its chief witness, who testified that the defendant took him to the site of the bodies and admitted to torturing and killing the two women. The witness's credibility was challenged by evidence of a substantial drug problem. See Spaziano, 393 So. 2d at 1119-20.

103. Spaziano, 468 U.S. at $456-57$.

104. Some states permit trial judges to instruct on lesser included offenses absent a request by the 
The Court emphasized that in the absence of a waiver of the limitations defense, Beck's central purposes would not be served:

The element the Court in Beck found essential to a fair trial was not simply a lesser included offense instruction in the abstract, but the enhanced rationality and reliability the existence of the instruction introduced into the jury's deliberations. Where no lesser included offense exists, a lesser included offense instruction detracts from, rather than enhances, the rationality of the process. ${ }^{105}$

The Court explained that Beck required lesser included offense instructions to avoid the risk that a jury might improperly convict a defendant due to all-or-nothing pressure to convict or acquit when the defendant was guilty only of the lesser offense. But the Court now emphasized that instructing on lesser included offenses of which the defendant could not be convicted introduced a new source of error: the risk jurors would compromise improperly by convicting of an offense that was in fact not legally available. The Court wrote:

We reaffirm our commitment to the demands of reliability in decisions involving death and to the defendant's right to the benefit of a lesser included offense instruction that may reduce the risk of unwarranted capital convictions. But we are unwilling to close our eyes to the social cost of petitioner's proposed rule. Beck does not require that the jury be tricked into believing that it has a choice of crimes for which to find the defendant guilty, if in reality there is no choice. Such a rule not only would undermine the public's confidence in the criminal justice system, but it also would do a serious disservice to the goal of rationality on which the Beck rule is based. ${ }^{106}$

Although one sentence in Spaziano broadly opined that Beck does not require instruction "[w]here no lesser included offense exists," 107 the Court was neither concerned with whether a less serious crime was defined as a lesser included offense under state law nor whether state rules made instruction available on the offense. Rather, the Court was dealing with the specific problem of whether a jury should be misled as to its power to convict

\footnotetext{
prosecution or defense. A number of scholars advocate removing the decision from trial counsel. See generally Catherine L. Carpenter, The All-Or-Nothing Doctrine in Criminal Cases: Independent Trial Strategyor Gamesmanship Gone Awry?, 26 Am. J. CRIM. L. 257, 300-03 (1999); Tracy L. Hamrick, Recent Development, Looking at Lesser Included Offenses on an "All or Nothing” Basis: State v. Ballard and the Sporting Approach to Criminal Justice, 69 N.C. L. Rev. 1470 (1991); Patrick D. Pflaum, Comment, Justice is Not All or Nothing: Preserving the Integrity of Criminal Trials Through the Statutory Abolition of the All-Or-Nothing Doctrine, 73 U. CoLo. L. Rev. 289, 293 (2002).

105. Spaziano, 468 U.S. at 455.

106. Id. at 456 .

107. See supra text accompanying note 105 (giving the quote in context).
} 
of a less serious crime when the defendant had valid legal defenses to conviction of such a crime of which the jury was unaware.

The Court's decision was narrow, but its rationale does not limit it to lesser included offenses that are barred by statute of limitations defenses. Because the Court's reasoning was grounded on the policy of not misleading juries about their power to convict of crimes to which defendants have unqualified defenses, Spaziano would provide strong authority that lesser included offense instructions need not be given when the defendant has complete defenses to the lesser included offenses that have not been waived. Examples of such legal defenses would be a defense of absolute immunity, a defense that the lesser included offense is barred by the Double Jeopardy Clause, or a defense that the trial court lacks jurisdiction to enter a valid judgment on the lesser included offense. Spaziano might likewise justify the refusal to instruct on lesser included offenses when those offenses are not supported by sufficient evidence and a conviction on them could not be sustained as a matter of law.

\section{Application of Beck to Noncapital Cases}

The Court's decision in Beck was limited to death penalty cases, and much of the Court's rationale for the decision emphasized the special risks of error present in death penalty cases. ${ }^{108}$ The Court acknowledged that "we have never held that a defendant is entitled to a lesser included offense instruction as a matter of due process" and that "there is a significant constitutional difference between the death penalty and lesser

108. The question presented was: "May a sentence of death constitutionally be imposed after a jury verdict of guilt of a capital offense, when the jury was not permitted to consider a verdict of guilt of a lesser included non-capital offense, and when the evidence would have supported such a verdict?" Beck v. Alabama, 447 U.S. 625, 627 (1980). The Court answered this question in the negative. Id. While the opinion recognized a right to lesser included offense instructions, it did not specifically ground the right either in the Eighth Amendment, U.S. Const. amend. VIII ("Excessive bail shall not be required, nor excessive fines imposed, nor cruel and unusual punishments inflicted."), or in the Due Process Clause, U.S. Const. amend XIV, $\S 1$ ("[N]or shall any State deprive any person of life, liberty, or property, without due process of law...."). Accordingly, student notes expressed regret about the uncertain constitutional source of the right. See Hall, supra note 11, at 1340 ("Unfortunately, it is not clear from its holding in Beck what the basis for the Court's decision was. While both due process and Eighth Amendment concerns come into play, neither one is indicated as the grounds for the holding."); Pattillo, supra note 96, at 441 ("Unfortunately, the question remains today: unconstitutional on what ground?"); Pflaum, supra note 104, at 306 ("Unfortunately, the Court did not clearly state what constitutional grounds it used to strike down the law."). 
punishments[.]"109 Moreover, the Court in cases construing Beck has taken pains to reassert that decision's special concern with risks of erroneous factfinding in capital cases. ${ }^{110}$ The Court has also cited the Beck decision in other cases for authority that the Constitution requires more procedural safeguards in death penalty cases than in other cases. ${ }^{111}$

The broad benefits attributed to lesser included offenses have led some scholars to champion a general constitutional requirement of lesser included offenses that would apply in noncapital contexts. ${ }^{112}$ But only the Third Circuit has recognized a constitutional right to lesser included offenses in noncapital cases. ${ }^{113}$ Other circuits and state courts have refused to extend Beck to noncapital cases ${ }^{114}$ and have generally concluded that cases are not capital for purposes of Beck when judgments do not include capital punishment, even though the defendants were tried for crimes that presented the risk of capital punishment. ${ }^{115}$

109. Beck, 447 U.S. at 637 . But see Hall, supra note 11, at 1342 (emphasizing uncertainty as to "whether the Supreme Court considered Beck limited to the capital context").

110. See Hopkins v. Reeves, 524 U.S. 88, $98-99$ (1998); Schad v. Arizona, 501 U.S. 624 (1991); Spaziano v. Florida, 468 U.S. 447 (1984); Hopper v. Evans, 456 U.S. 605 (1982).

111. E.g., Gilmore v. Taylor, 508 U.S. 333, 342 (1993) (citing Beck for authority that the Eighth Amendment requires greater factfinding accuracy in capital than in noncapital cases); Herrera v. Collins, 506 U.S. 390, 399 (1993) (citing Beck for authority that "[i]n capital cases, we have required additional protections because of the nature of the penalty at stake"); Murray v. Giarratano, 492 U.S. 1, 8 (1989) (citing Beck for authority that "the Constitution places special constraints on the procedures used to convict an accused of a capital offense and sentence him to death").

112. Hall, supra note 11, at 1362; Michael H. Hoffheimer, Habeas Corpus Review of State Trial Court Failure to Give Lesser Included Offense Instructions, 16 U. Mich. J.L. REFORM 617 (1983).

113. Vujosevic v. Rafferty, 844 F.2d 1023, 1027 (3d Cir. 1988) (reversing denial of habeas corpus relief where a prisoner convicted of noncapital murder in state court was denied a lesser included offense instruction on aggravated assault and the defense theory challenged the evidence of causation with respect to homicide).

114. Pitts v. Lockhart, 911 F.2d 109, 112 (8th Cir. 1990); Bagby v. Sowders, 894 F.2d 792, 797 (6th Cir. 1990); Chavez v. Kerby, 848 F.2d 1101, 1103 (10th Cir. 1988); Vallens v. Lynaugh, 835 F.2d 126, 127 (5th Cir. 1988); Woratzeck v. Ricketts, 820 F.2d 1450, 1457 (9th Cir. 1987), vacated on other grounds, 486 U.S. 1051 (1988); Perry v. Smith, 810 F.2d 1078, 1080 (11th Cir. 1987); State v. Nicholson, 435 N.W.2d 298, 302 (Wis. 1988). See generally Hoffheimer, supra note 11, at 404 (discussing cases); Pattillo, supra note 96, at 455-56 (discussing cases); Pflaum, supra note 104, at 311-12 (discussing cases); Shellenberger \& Strazzella, supra note 17, at 43-44, 56-66 (discussing cases and thoroughly evaluating authority for extension of Beck to noncapital cases).

115. E.g., Turner v. Marshall, 63 F.3d 807, 818-19 (9th Cir. 1995); Pitts, 911 F.2d at 112; Trujillo v. Sullivan, 815 F.2d 597, 604 (10th Cir. 1987); see also Rembert v. Dugger, 842 F.2d 301, 303 (11 th Cir. 1988) (holding that the omission of a lesser included offense instruction in a capital trial was harmless error where the defendant was sentenced to life imprisonment). See generally Nicholson, 435 N.W.2d at 302-03 (containing a full discussion of the constitutional source of the right and the reason for its limitation to death penalty cases); Pattillo, supra note 96, at 451-52 (discussing cases). 
Both the deep historical roots of lesser included offenses and the need for such instructions to assure accurate factfinding on critical issues may lead the Supreme Court one day to recognize a broader, constitutionally based right to lesser included offense instructions. At the same time, states are experimenting with revising longstanding principles of lesser included offense law, and it is questionable whether the Court will want to craft constitutional standards that would eliminate state control over jury instructions or that would involve federal courts in supervising jury instructions. Accordingly, the Court will probably continue to avoid promulgating a general requirement of lesser included offenses.

\section{Constitutional Deference to State Definitions of Offenses}

Hopkins v. Reeves ${ }^{116}$ held that Beck does not require a state to give lesser offense instructions in a capital case where state law does not contain any lesser offense that qualifies as a lesser included offense of the crime charged. The decision limits a defendant's power to prevent juries from being faced with all-or-nothing choices in capital cases and Justice Stevens, the author of Beck, dissented. ${ }^{117}$ Justice Thomas, writing for the Court, insisted that Beck was never meant to require states to create lesser included offenses in order to avoid the undesirable all-or-nothing dilemma. ${ }^{118}$ His opinion restricted the scope of Beck, but his explanation generates uncertainty about the decision's application in other contexts.

The defendant in Hopkins was convicted in Nebraska of two counts of first-degree murder for killings committed during the commission of or attempt to commit rape. ${ }^{19}$ Under Nebraska law capital felony murder required no proof of intent to kill; it required proof only that the defendant caused death during the commission or attempt to commit sexual assault. ${ }^{120}$ The trial court denied defendant's request for instructions on noncapital second-degree murder and manslaughter because Nebraska courts had

116. 524 U.S. 88 (1998). Hopkins reversed a decision from the Eighth Circuit holding that Nebraska was required to give lesser included offense instructions, Reeves v. Hopkins, 102 F.3d 977 (8th Cir. 1996), and approved the position adopted by the Ninth Circuit that lesser homicide instructions were not required in a capital felony murder prosecution where state law did not recognize the less serious crimes as lesser included offenses of capital murder, Greenawalt v. Ricketts, 943 F.2d 1020, 1029 (9th Cir. 1991), cert. denied, 506 U.S. 888 (1992).

117. Hopkins, 524 U.S. at 101-02 (Stevens, J., dissenting).

118. Id. at $96-98$ (majority opinion).

119. Id. at 91 (citing Neb. Rev. Stat. § 28-303 (1995)).

120. Id. at 91-92 (citing State v. Reeves, 344 N.W.2d 433, 442 (Neb. 1984)). 
consistently held that those crimes were not lesser included offenses of felony murder. ${ }^{121}$

Finding that the requested instructions were not constitutionally required, the Supreme Court distinguished the facts of the case and the Nebraska trial procedures from those in Beck. The Court's opinion supports a number of possible interpretations about what it now sees as the critical constitutional failure of the Alabama procedures in Beck.

\section{A. Avoiding the Easy Case}

Hopkins attracted relatively little attention, ${ }^{122}$ perhaps because its result was unobjectionable and because the Court's opinion limited the potential scope of the decision. ${ }^{123}$ Both physical evidence and the defendant's admission established that he raped two victims who died during or shortly after the attacks. Nebraska prosecuted the defendant for felony murder, a crime that required proof only that the defendant caused death in the commission of or attempt to commit sexual assault. The legislature fixed punishment for this crime to include capital punishment.

Under settled legal principles in Nebraska, as in most jurisdictions, the defendant would be no more entitled to lesser included offense instructions than to self-defense instructions. To be sure, the defendant's criminal conduct established proof of other crimes (including second-degree murder and manslaughter). But Nebraska was not required to prove the elements of those crimes in order to prevail on the felony-murder charge. In striking contrast to $B e c k$, the Nebraska jury was not required to find additional facts in order to

121. Id. at 92 .

122. The few responses to the decision have been fiercely critical. See Peter A. Barta, Note, Between Death and a Hard Place: Hopkins v. Reeves and the "Stark Choice" Between Capital Conviction and Outright Acquittal, 37 AM. CRIM. L. REv. 1429 (2000) (offering a detailed critique of Justice Thomas's rationale in Hopkins); Hall, supra note 11, at 1350 ("The outcome of Hopkins is troubling because it further reduces the already limited rights of capital defendants.... Whether the judge or the State would find the 'third option' technically a [lesser included offense] or not would not, in all probability, have any impact on the jury's deliberations and should, therefore, play no role in determining whether or not a defendant is constitutionally entitled to such an instruction."); Pattillo, supra note 96, at 448 ("Reeves is a difficult and disturbing case because it demonstrates that the capital defendant's constitutional right to [a lesser included offense instruction] as a 'third option' only goes so far as legislatures draft offenses to have [lesser inclu ded offenses] and courts interpret offenses to constitute [lesser included offenses]. Reeves suggests that Beck affords a right that can potentially be drafted out of existence.").

123. See Alix Marie Karl, Case Note, United States Supreme Court: Hopkins v. Reeves, $118 \mathrm{~S}$. Ct. 1895 (1998), 11 CAP. DEF. J. 53, 56 (1998) (observing that Reeves would not affect practice in Virginia, where capital murder requires proof of intent to kill). 
convict of the capital offense. Thus, the failure to give lesser included offense instructions on noncapital forms of homicide did not create a risk of error on the element that qualified the crime for capital punishment. On the contrary, again in contrast to Beck, the elements that distinguished capital and noncapital crimes were not contested. ${ }^{124}$ In other words, the instructions were not warranted by the evidence, and giving the instructions would merely empower the jury to compromise improperly by returning a verdict on a lesser offense. Similarly, while the defendant would undoubtedly have preferred to be prosecuted for criminal trespass rather than any form of murder, he was not entitled to lesser included offense instructions on that crime because reasonable factfinders would not conclude that he was guilty of the lesser offense but not the greater. ${ }^{125}$

Hopkins should have been an easy case. The opinion could have explained how Nebraska's failure to give lesser included offense instructions did not offend Beck for the reason that while the omission of lesser included offense instructions denied the jury the possibility of a merciful compromise verdict, it did so in a case where such a compromise was not supported by the evidence. In short, the Nebraska jury was not pressured into erroneous factfinding. Rather, at least one of the requested instructions required the jury to find additional facts that the prosecution did not need to prove and did not put in evidence. ${ }^{126}$

124. The defendant raised a not guilty by reason of insanity defense. Hopkins, 524 U.S. at 98 .

125. The right to a jury trial does not create a right to lesser included offense instructions. Although a minority of states permit lesser included offense instructions regardless of the evidence as a matter of state law, the Supreme Court made clear that there is no general right to lesser included offenses just because there may be sufficient evidence to convict of the lesser offense. Berra v. United States, 351 U.S. 131 (1956) (affirming a conviction of willful tax evasion despite the failure to instruct the jury on the lesser crime of submitting a fraudulent return); Sparf v. United States, 156 U.S. 51, 63-64 (1895) (affirming a murder conviction despite the failure to instruct on manslaughter); $c f$. Michael H. Hoffheimer, Lesser Included Offenses in Mississippi, 74 Miss. L.J. 135, 147-48 (2004) (discussing Sparf v. United States). Since the 1800 s most jurisdictions have required as a prerequisite for submitting lesser included offense instructions that there be an evidentiary dispute regarding the facts that differentiate the greater and lesser offense so that a reasonable factfinder could convict of the lesser but not the greater offense. See Schmuck v. United States, 489 U.S. 705, 716 \& n.8 (1989); Hoffheimer, supra note 11, at 360-61; Shellenberger \& Strazzella, supra note 17, at 7 ("Not only must the evidence support a conviction for the [lesser offense], it must also support an acquittal of the greater offense. In other words, there must be a rational factual dispute about the element or elements that differentiate the greater and lesser offenses.").

126.

Nebraska proceeded against respondent only on a theory of felony murder .... The State therefore assumed the obligation of proving only that crime[; . . . its entire case focused solely on that obligation. To allow respondent to be convicted of homicide offenses that are not lesser included offenses of felony murder, therefore, would be to allow his jury to find beyond a reasonable doubt elements that the State had not attempted to prove, and indeed that it had ignored during the course 
But Justice Thomas avoided the most obvious explanation for the Court's decision. Instead, he focused on formal differences between the offenses charged in Beck and Hopkins. Perhaps one reason why the Court avoided finding that the lesser offense charge was not required under the facts was that such a finding might have been vulnerable to the objection (articulated by the dissenting opinion) that, although lesser included offense instructions were not required to promote accurate factfinding on elements of the offense as defined by state law, such factfinding would nevertheless be required because the Constitution required Nebraska to establish intent to kill in capital cases. ${ }^{127}$

\section{B. Impermissible State Distinctions Between Capital and Noncapital Prosecutions}

Rather than explaining how the Nebraska procedure in Hopkins did not pose a risk of erroneous factfinding, the Court focused on formal elements that distinguished the impermissible Alabama procedure in Beck from the permissible Nebraska procedure in Hopkins. Justice Thomas paid special attention to the fact that Alabama had refused to give lesser included offense instructions only in capital cases, whereas the Nebraska courts had refused to give other homicide instructions in felony-murder prosecutions whether or not the death penalty was sought because the Nebraska courts held that seconddegree murder and manslaughter were not lesser included offenses of felony murder. ${ }^{128}$

The Court's attention in Hopkins to differential state practices in capital and noncapital prosecutions was not supported by the Court's prior decisions. In fact the Court in Beck had refused to rule on an equal protection challenge based on such differential practices because the issue had not been properly presented. ${ }^{129}$ The Court's distinction would make sense in the context of a

of trial. This can hardly be said to be a reliable result .... Hopkins, 524 U.S. at 99.

127.

The reason that Nebraska generally does not consider second-degree murder a lesser included offense of felony murder is that it requires evidence of an intent to cause the death of the victim, whereas felony murder does not. But in this case the State sought to impose the death penalty.... As a matter of federal constitutional law ... it could not do so without proving that respondent intended to kill his victim, or ... that he had the moral equivalent of such an intent. Id. at 101-02 (Stevens, J., dissenting) (citations omitted).

128. Id. at 96 (majority opinion) ("Alabama thus erected an 'artificial barrier' that restricted its juries to a choice between conviction for a capital offense and acquittal."). Justice Thomas cited a solicitor general's amicus curiae brief for this point. $I d$.

129. The defendant also raised an equal protection issue, U.S. Const. amend. XIV, based on 
death penalty jurisprudence that, alert to the special dangers raised in capital prosecutions, disfavored the establishment of practices unique to capital cases that enhanced the risk of wrongful conviction. But while the heightened concern with capital punishment explains the restriction of the Beck rule to death penalty cases,${ }^{130}$ it does not explain why a state's refusal to give lesser included offense instructions only in capital cases would be especially troubling or, conversely, why its refusal to give such instructions in some noncapital cases would reduce the all-or-nothing pressure to convict in capital cases.

Justice Thomas's emphasis on the formal limitation of Alabama's rule to capital cases has the effect of limiting Beck to its facts, but the policy served by this distinction is uncertain and its application raises new questions. For example, while Justice Thomas insisted that the Alabama procedure in Beck applied exclusively to prosecutions for capital crimes, ${ }^{131}$ that procedure was not limited to cases where the death penalty was imposed or even to cases where it could be imposed. ${ }^{132}$ Indeed, some persons convicted of capital murder would not be eligible for capital punishment, ${ }^{133}$ and the death penalty could not be automatically imposed upon conviction even for those who might be death eligible. ${ }^{134}$

In contrast, Justice Thomas emphasized that Nebraska permitted lesser included offense instructions in some kinds of first-degree murder cases and withheld lesser included homicide offense instructions in felony-murder trials

Alabama's refusal to give lesser included offense instructions only in capital cases, but the Court did not address this issue because it was not raised below. Beck v. Alabama, 447 U.S. 625, 632-33 n.8 (1980).

130. The Court's careful discussion of the Alabama distinction was also explained by 1 ) its finding that the Alabama practice was idiosyncratic and 2) its rejection of Alabama's contention that lesser included offenses would promote improper jury compromise. Id. at 633.

131. This was true because the procedure was imposed by statutes that regulated capital murder prosecutions. Id. at 627-29.

132. Defendants convicted of capital murder were not necessarily sentenced to death under Alabama law at the time. AlA. CODE $§ 13-11-3$ (1975) (providing for a judicial hearing before sentencing at which evidence is received and arguments are presented for or against the imposition of a death sentence). In addition, nothing in Alabama law would prevent a prosecutor in a case like Beck from charging and winning a conviction for simple murder.

133. The Constitution requires individual culpability with respect to the homicide. Tison v. Arizona, 481 U.S. 137 (1987) (requiring the moral equivalent of an intent to kill as a prerequisite for imposition of the death penalty); Enmund v. Florida, 458 U.S. 782 (1982) (requiring proof of intent to kill as a prerequisite for imposition of the death penalty). Such culpability is not required for a conviction of capital murder in Alabama.

134. Woodson v. North Carolina, 428 U.S. 280 (1976) (holding mandatory death penalty unconstitutional). 
and even in non-death penalty cases. ${ }^{135}$ But he did not explain the source of Nebraska's classification of felony murder into capital and noncapital crimes. In theory, Nebraska's refusal to recognize lesser included offenses to felony murder was inconsistent with the state's general definition of lesser included offenses. Yet, as Peter Barta observed, Justice Thomas did not acknowledge or address the fact that the State treated lesser included offenses differently in the context of felony murder. ${ }^{136}$ The Court did not satisfactorily explain how Nebraska's result-oriented characterization that felony murder lacked lesser included offenses differed from Alabama's legislative elimination of lesser included offenses specifically for capital murder. ${ }^{137}$

Justice Thomas's emphasis on the fact that felony murder was not necessarily a capital offense is baffling. Whether or not the crime was prosecuted as a capital offense appears to have been a matter of prosecutorial discretion. ${ }^{138}$ This discretion is indistinguishable as a matter of practice from the kind of discretion that an Alabama prosecutor would enjoy to indict the defendant in Beck of either capital or simple murder, or indeed to acquiesce in the defendant's post-conviction arguments against imposition of the death penalty.

\section{Exclusive State Authority to Define Lesser Included Offenses}

Justice Thomas assumed that Beck required deference to state law regarding the existence of lesser included offenses. He explained the "crucial distinction" between Beck and Hopkins as "the distinction between a State's

135.

In Nebraska, instructions on offenses that have been determined to be lesser included offenses of the charged crime are available to defendants when the evidence supports them, in capital and noncapital cases alike. Respondent's proposed instructions were refused because the Nebraska Supreme Court has held for over 100 years, in both capital and noncapital cases, that seconddegree murder and manslaughter are not lesser included offenses of felony murder. Hopkins v. Reeves, 524 U.S. 88, 95 (1998) (emphasis added).

136. Barta, supra note 122, at 1455 ("Without citing to or even acknowledging the existence of [Nebraska's statutory definition of lesser included offenses], Justice Thomas simply accepted Nebraska's contention that, as a matter of uncontroverted state law, second-degree murder and manslaughter are not lesser included offenses of felony murder.”).

137. Pattillo, supra note 96, at 450 ("It is hard to see how the Nebraska legislature's drafting of its felony murder offense so as to preclude any [lesser included offense] instructions is, as a practical matter, much different from Alabama's direct prohibition ... struck down in Beck.").

138. Justice Thomas himself acknowled ged that Nebraska authority prevented lesser included offense instructions in felony murder prosecutions, regardless of whether the felony murder was prosecuted as a capital crime. See supra note 135 and accompanying text. There is no explanation, however, as to how Nebraska prosecutors determined when to prosecute felony murder as a capital crime. 
prohibiting instructions on offenses that the state law recognizes as lesser included, and a State's refusing to instruct on offenses that state law does not recognize as lesser included." ${ }^{139}$ He concluded that felony murder was a lesser included offense under Alabama law (despite the fact that Alabama law prohibited the giving of such an instruction in Beck) while second-degree murder and manslaughter were not lesser included offenses under Nebraska law. ${ }^{140} \mathrm{He}$ insisted that constitutionally requiring lesser included offense instructions would radically alter Nebraska state law by mandating the creation of new offenses that did not previously exist. ${ }^{141}$

The Court's opinion manifested the underlying conviction that Beck operated on a preexisting body of state criminal offenses in a way that made it possible to determine objectively as a matter of state law whether offenses are lesser included offenses of some greater crime. But the opinion did not elaborate on how this determination should be made. There are four different ways in which the Court could find that second-degree murder and manslaughter are not lesser included offenses of first-degree felony murder as a matter of Nebraska law. First, the Court could refer to the formal definition of the crimes and examine the elements so as to determine whether the less serious crimes required proof of additional facts not required for the charged capital offense. ${ }^{142}$ Second, the Court could look at the evidence necessary to prove the greater offense to determine whether it was necessarily sufficient to establish the lesser offenses as well. Third, the Court could look to the state's characterization of those crimes - that is, ask whether the state itself called the lesser crimes "lesser included offenses." Fourth, the Court could inquire whether the state courts permitted instruction on the lesser offenses. ${ }^{143}$

Unfortunately, the Court did not examine why the Nebraska court had consistently refused to permit convictions of less serious homicides in felonymurder trials. ${ }^{144}$ The state's prohibition on joinder of first-degree murder and

139. Hopkins, 524 U.S. at 99 n.7.

140. Id. at $95-96$.

141. Id. at 96; see infra text accompanying note 149 .

142. Id. at $92 \mathrm{n} .1$ (observing that second-degree murder required proof of intent and that manslaughter required either proof of intentional killing without malice during a sudden quarrel or proof of unintentional killing during an unlawful act).

143. The Court remarked that "the Nebraska Supreme Court has held for over 100 years, in both capital and noncapital cases, that second-degree murder and manslaughter are not lesser included offenses of felony murder." Id. at 95 .

144. The Supreme Court stated that under Nebraska law, a prosecutor could not secure convictions for second-degree murder or manslaughter under an indictment for first-degree felony murder and that such a conviction would be reversible error. $I d$. at 96 (citing Thompson v. State, 184 N.W. 68, 68 (Neb. 1921)). In fact, the Nebraska cases seemed to hold more modestly that the omission of lesser homicide instructions 
lower homicide offenses may have been designed originally for the benefit of defendants to prevent scattershot charges or to eliminate the possibility of compromise verdicts. Such state benefits would not accrue in a case where the elements distinguishing first-degree and lower forms of homicide liability were at issue. Moreover, the defendant's request for jury instructions on the lesser offenses unequivocally communicated his desire to waive any objections to possible disadvantages of joinder in order to secure the benefits of avoiding the all-or-nothing choice stated in Beck.

Justice Thomas asserted that Nebraska's policy of withholding lesser homicide instructions differed fundamentally from the Alabama practice the Court found unconstitutional in Beck. He found two critical distinctions between the practices. First, "[t]he Alabama statute prohibited instructions on offenses that state law clearly recognized as lesser included offenses of the charged crime," and, second, "it did so only in capital cases."145

Justice Thomas then went on to explain more broadly that Beck prevents a state from withholding lesser included offense instructions normally available under state law in capital cases in order to remove the all-or-nothing pressure to commit. ${ }^{146}$ At the same time, he emphasized that Beck did not require states to create lesser included offenses in order to reduce the pressure to convict that might exist in the absence of such lesser offense options. ${ }^{147}$ This was consistent with the Court's prior observation that "[w] here no lesser included offense exists, a lesser included offense instruction detracts from, rather than enhances, the rationality of the process. Beck does not require that result." 148

Justice Thomas emphasized that deference to state law regarding the existence of lesser included offenses was important to preserve state sovereignty. He wrote:

By ignoring these distinctions, the Court of Appeals limited state sovereignty in a manner more severe than the rule in Beck. Almost all States, including Nebraska, provide instructions only on those offenses that have been deemed to constitute lesser included offenses of the charged crime. We have never suggested that the Constitution requires anything more. The Court of Appeals in this case, however, required in effect that States create lesser included offenses to all capital crimes, by requiring that an instruction be

was not error in a rape-murder prosecution, Morgan v. State, 71 N.W. 788 (Neb. 1897), and that a conviction for manslaughter was reversible error where the defendant objected to submission of the lesser included offense, Thompson, 184 N.W. at 68.

145. Hopkins, 524 U.S. at 96.

146. $I d$.

147. $I d$.

148. Spaziano v. Florida, 468 U.S. 447, 455 (1984). 
given on some other offense-what could be called a "lesser related offense" - when no lesser included offense exists. ${ }^{149}$

An accompanying footnote explained that states have adopted a variety of definitions of lesser included offenses and that Nebraska in particular had alternated between the elements test of lesser included offenses and the cognate evidence approach. ${ }^{150}$ The Court did not consider whether lesser homicide crimes would have satisfied either approach's criteria for lesser included offenses but noted simply that despite the fluctuation in Nebraska's general law, state opinions had consistently held that felony murder has no lesser included offenses. ${ }^{151}$

Justice Thomas also distinguished the procedures in Beck and Hopkins on the ground that the jury in Beck was required to sentence to death upon conviction of capital murder whereas capital sentencing in Hopkins was conducted by a trial court and sentencing options were not limited to death. ${ }^{152}$ However, the opinion did not explain how this procedural distinction might reduce the risk of wrongful conviction posed by all-or-nothing jury instructions on the capital crime. The Beck Court had expressly concluded that the risk of such error at the guilt phase could not be cured by alternatives at the sentencing phase, ${ }^{153}$ and this determination was a necessary part of the Court's rejection of Alabama's argument that the omission of lesser offense instructions benefitted the defendant. But Justice Thomas suggested the possibility of reaching a different conclusion in Hopkins, ${ }^{154}$ and the opinion

149. Hopkins, 524 U.S. at 96-97 (citation and footnote omitted).

150. The elements test defines a lesser included offense as a crime whose elements are a subset of the elements of the more serious crime. The cognate evidence approach defines a lesser included offense as a less serious crime whose commission is necessarily proved by evidence that proves the commission of a more serious crime. See generally Hoffheimer, supra note 11, at 411-15 (discussing state definitions of lesser included offenses).

151. Hopkins, 524 U.S. at 96 n.6.

152. Id. at $98-99$.

153.

The State's second argument is that, even if a defendant is erroneously convicted, the fact that the judge has the ultimate sentencing power will ensure that he is not improperly sentenced to death. Again, we are not persuaded that sentencing by the judge compensates for the risk that the jury may return an improper verdict because of the unavailability of a "third option."

Beck v. Alabama, 447 U.S. 625, 645 (1980). The Court made the obvious point that a jury that convicted only of a lesser included noncapital offense would not leave the sentencing court the opportunity to impose death. $I d$.

154. Hopkins, 524 U.S. at 99 n.7 ("We are not, of course, presented with a case that differs from Beck only in that the jury is not the sentencer, and we express no opinion here whether that difference alone would render Beck inapplicable.”). 
has been criticized for encouraging states to do indirectly exactly what Beck prohibited them from doing directly. ${ }^{155}$

\section{Need for Judicial Clarification}

The Supreme Court recognizes that it must resolve the question of how Justice Thomas's deference to state law in Hopkins can be reconciled with Beck's constitutional mandate that states give lesser included offense instructions. In 2004 the Court granted a writ of certiorari in Howell v. Mississippi, ${ }^{156}$ a capital case where state courts refused to require lesser included offense instructions for the reason that they concluded the instructions were not supported by the evidence. Unfortunately, in 2005 the Court dismissed the writ as improvidently granted prior to addressing the constitutional issue of whether state law controlled the issue of when lesser included offense instructions must be given. ${ }^{157}$

155.

Because Reeves does not explicitly overrule Beck, states are still prohibited from adopting an acrossthe-board prohibition on the charging of lesser included offenses in all capital cases. There is, however, nothing in the Court's decision to prohibit other states from emulating Nebraska and accomplishing the same effect through a piecemeal approach. Instead of issuing a blanket rule covering all capital offenses, state legislatures may now redefine the elements of individual capital crimes, such as felony murder, as having no lesser included offenses. Protected by the shield of "state autonomy," each of these newly minted offenses can then be presented to capital juries as the sort of "yes" or "no" proposition condemned in Beck.

Barta, supra note 122 , at 1471.

156. 542 U.S. 936 (2004).

157. Howell v. Mississippi, 125 S. Ct. 856 (2005). The Court dismissed the case because the defendant had not identified the federal source of the right on appeal to the state supreme court. $I d$. at 860 . Justice Rehnquist dissented in Beck on the ground that the defendant had not adequately presented the federal constitutional issue to the state courts. Beck, 447 U.S. at 646-48 (Rehnquist, J., dissenting). The Court clarified in Howell that a defendant must present the federal constitutional error to the state appellate courts as a prerequisite for Supreme Court review by writ of certiorari. The Court reserved the issue of whether this is a jurisdictional requirement but strongly suggested that it might be one.

Notwithstanding the long line of cases clearly stating that the presentation requirement is jurisdictional, a handful of exceptions have previously led us to conclude that this is "an unsettled question." As in prior cases, however, we need not decide today "whether our requirement that a federal claim be addressed or properly presented in state court is jurisdictional or prudential, because even treating the rule as purely prudential, the circumstances here justify no exception." Howell, 125 S. Ct. at 860 (citations omitted) (quoting Adams v. Robertson, 520 U.S. 83, 90 (1997)). 


\section{A. Loss of Meritorious Issues in a Sea of Error}

The proceedings in Howell v. Mississippi provide a textbook example of much of what is wrong with American death penalty litigation. The defendant, a young African-American male, was charged with capital murder for the shooting death of a white victim. ${ }^{158}$ The case was tried before an allwhite jury after prosecutors removed all African-Americans from the jury panel. ${ }^{159}$ Because the indigent defendant was represented pro bono rather than by court-appointed counsel, ${ }^{160}$ the trial court denied requests for state funds for investigation and for the appointment of an additional lawyer to assist in the defense. ${ }^{161}$

The state's evidence consisted of an accomplice and an eyewitness who saw the defendant approach the victim's car and shoot and kill the victim. ${ }^{162}$ Although no robbery was completed, prosecution witnesses testified that the defendant stated prior to the killing that he needed money ${ }^{163}$ and that he had referred to the victim as "an easy lick." 164

The defendant raised two different defenses. First, the defense presented alibi evidence. ${ }^{165}$ Second, the defense contested the evidence of an attempted robbery by pointing out that the robbery was not completed and that statements attributed to the defendant were consistent with other motives such as the intent to sell drugs to the victim. ${ }^{166}$

158. Howell, 125 S. Ct. at 857.

159. It is clear only from the dissenting opinion that the effect of the prosecution's peremptory challenges of two African-American jurors was to yield an all-white trial jury. Howell v. State, 860 So. $2 d$ 704, 766 (Miss. 2003) (Graves, J., dissenting) (“'T] The State exercised peremptory challenges on both jurors, thus eliminating any African-American jurors from service in the trial of Howell, an African-American defendant."). The eyewitness was white, and the trial court refused a requested instruction cautioning the jury on the risk of error in cross-racial identification. Id. at 748 .

160. Howell's lawyer, Duncan L. Lott, represented him on a pro bono basis both at trial and on direct appeal as a favor to the defendant's father. $I d$. at 720 .

161. Id. at 722. The state supreme court found no error, though it noted that in capital cases Mississippi routinely appoints two trial lawyers to represent the accused. Id.

162. Id. at $712-15$.

163. The statements identified the defendant's need for money as debts to his parole officer. Though these constituted evidence of crimes, the trial court admitted them because their probative value in establishing motive outweighed their prejudicial effect. The state supreme court affirmed. Id. at 733.

164. Id. at 713 .

165. Id. at 741 .

166. The defendant did not testify and objected when the prosecutor during closing argument effectively commented on the defendant's failure to testify by remarking, "If you had an alibi and were accused of capital murder, don't you think you would tell somebody about it. Don't you think you would have given some details. Done something. That is common sense." Id. at 751 (quoting closing argument). The state supreme court held that no reversible error occurred because "[a]ttorneys are allowed wide latitude 
The trial court instructed the jury solely on capital murder, a crime that required proof of homicide during an attempt to commit robbery. ${ }^{167}$ The defendant requested instructions on various forms of homicide available under state law, including depraved-heart murder, ${ }^{168}$ deliberate-design murder, ${ }^{169}$ and culpable-negligence manslaughter. ${ }^{170}$ The State opposed lesser included offense instructions at trial, arguing in effect both that the evidence did not support the submission of lesser included offenses and that the requested instructions were not lesser included offenses under the prosecution's theory of the case. ${ }^{171}$

The trial court refused to instruct on noncapital offenses, and the jury found the defendant guilty of capital murder. He was sentenced to death by lethal injection, while his accomplice pleaded guilty to manslaughter and robbery and was sentenced to thirty years in prison. ${ }^{172}$

The Mississippi Supreme Court, the only court to review the proceedings, considered twenty-eight errors on direct appeal. Several of these were sufficiently meritorious that members of the court expressed concern, and two voted to reverse. ${ }^{173}$ Issue 14 , which raised the refusal to instruct on lesser

in closing arguments [and] [t]he trial judge is in the best a [sic] position to determine if an alleged objectionable remark has a prejudicial effect." $I d$. (citation omitted). Justice Graves concluded that such comments violated established rules prohibiting prosecutorial comment on a defendant's failure to testify. Id. at 769 (Graves, J., dissenting) (citing Taylor v. State, 672 So. 2d 1246, 1266 (Miss. 1996)).

167. Miss. Code ANN. §97-3-19(1), (2)(e) (2000) ("The killing of a human being ... shall be capital murder . . . [w]hen done with or without any design to effect death, by any person engaged in the commission of the crime of . . robbery . . or in any attempt to commit such felonies."). The instruction given to the jury did not quote the statute or set out the elements of capital murder but rather crossreferenced the definition of capital murder in the indictment. See Howell, 860 So. 2d at 741 (quoting instruction).

168. Defendant's requested instruction D-13 was based on a form of simple murder that required "an act imminently dangerous to others and evidencing a depraved heart, regardless of human life." Howell, 860 So. $2 d$ at 741-42 (quoting requested instruction, which paraphrases $\S 97-3-19(1)(b)$ ). For the elements of unintentional homicide and their judicial elaboration, see Michael H. Hoffheimer, Murder and Manslaughter in Mississippi, 71 Miss. L.J. 35, 105-37 (2001).

169. The defense also requested instruction D-18. Howell, 860 So. $2 \mathrm{~d}$ at 743 (quoting requested instruction, which paraphrases $\S 97-3-19(1)(a))$.

170. Id. at 741-44; see also § 97-3-47.

171. The prosecutor stated that there was no "premeditation and deliberate design which is a necessary element to prove simple murder." Howell, 860 So. $2 \mathrm{~d}$ at 742 (quoting prosecutor's colloquy). In fact neither premeditation, deliberate design, nor intent were required for simple murder under the defendant's proposed instructions, but some form of those crimes was presumably incorporated in the state instructions that were withdrawn. Similarly, the prosecutor emphasized that manslaughter required the proof of the additional element of culpable negligence, which the prosecution was not required to establish for capital murder based on felony murder. $I d$. at 742-43 (quoting prosecutor's colloquy).

172. Id. at 714 .

173. Two justices voted to reverse for three errors unrelated to jury instructions. Id. at 766-69 
included offenses, did not attract special attention. ${ }^{174}$ The court's opinion described and quoted the trial record and then disposed of the issue in a few words: "The facts of this case clearly do not support or warrant such instructions." 175

After the court affirmed, experienced death penalty litigators reviewed the record and recognized that the refusal to instruct on noncapital lesser included offenses potentially violated established constitutional rights under Beck. But, because the specific federal source of the right was not raised on direct appeal, the Supreme Court refused to decide the issue and dismissed the case. ${ }^{176}$

\section{B. Distinctions with a Difference in Denying Lesser Included Offense Instructions}

Howell's case history illustrates the special difficulty that can arise in characterizing why a court decides not to give lesser included offense instructions. Where a defendant charged with capital murder did not contest the facts of the homicide but denied only that he was the killer, he or she would not normally seek, or be entitled to, lesser included offense instructions. But where a defendant challenged both the identification of the killer and evidence that the killing was capital murder, ${ }^{177}$ lesser included offense instructions would be given in all states if two conditions were met. First, the lesser offenses must properly qualify as lesser included offenses to

(Graves \& McRae, JJ., dissenting). Five justices wrote specially to express concern regarding a fourth issue unrelated to jury instructions. Id. at 765-66 (Pittman, C.J., Waller, Cobb \& Carlson, JJ., concurring; Graves, J., concurring in part).

174. Press coverage inaccurately suggested this issue was of particular prominence before the state courts. See Hailee Lampert, Medill School of Journalism, On the Docket: Howell, Marlon (aka Cox, Marlon) v. Mississippi, Medill News Serv., July 13, 2004, http://www.medill.north western.edu/ secure/ docket/mt/archives/000888.php (summarizing case history and observing that the defendant raised twentyeight issues on appeal but "[p]rimarily" raised a claim of error regarding the failure to give lesser included offense instructions).

175. Howell, 860 So. $2 \mathrm{~d}$ at 744 . The court cited no specific features of the case that explained this conclusion but merely quoted language from a prior opinion to the effect that unwarranted instructions should not be given. Id. (citing Grace v. State, 375 So. 2d 419, 420 (Miss. 1979)).

The trial record was unclear as to whether the defendant even requested depraved-heart murder instruction and whether the trial court denied such a request. The State pointed this out during briefing before the Supreme Court. Brief of Respondent at 5 n.2, 38 n.17, Howell v. Mississippi, 125 S. Ct. 856 (2005) (No. 03-9560) [hereinafter Brief for Respondent]. But the state supreme court quoted all instructions in the record and held categorically that the trial court properly refused them all.

176. Howell v. Mississippi, 125 S. Ct. 856, 857-58 (2005).

177. To be sure, raising multiple defenses would be imprudent in many cases because doing so would erode the credibility of the separate defenses. 
the capital crime. Second, there must be some question of fact regarding the elements that differentiate the greater and lesser included offenses.

\section{Ambiguity of Reasons for State Court Decisions}

Mississippi courts, like those of all other states, would require lesser included offense instructions in a capital robbery-murder case where the robbery was in dispute. A close reading of the case history reveals that the reason for the court's refusal to give instructions in Howell is ambiguous.

The defendant in Howell contended that robbery evidence was equivocal and could also support a finding that the defendant approached the victim to obtain money by selling drugs. ${ }^{178}$ The State responded to this contention with two different arguments. First, the State argued that murder and manslaughter were not lesser included offenses of the form of capital murder charged against the defendant because those less serious crimes require proof of additional culpable mental states that are not required for capital felony murder. ${ }^{179}$ Second, the State argued that murder and manslaughter instructions should not be given because the defendant's claim that there was a factual dispute about the robbery was based on a speculative characterization of the evidence. ${ }^{180}$

178. At trial defendant argued that "there was absolutely nothing to believe there was a robbery going on. This jury can find that [defendant] was there and did shoot [the victim] . . . but based on [witness's] testimony there was no robbery going on and therefore . . . for whatever reason he shot him it's manslaughter." Howell, 860 So. 2 d at 743 (quoting defense counsel). On appeal the defendant argued, "The fact remains that if this jury had believed Howell approached [victim's] vehicle to sell him drugs and was sprayed in the face with mace[,] then they could have returned a conviction on manslaughter." Id. at 744. In briefing before the Supreme Court, the defense advanced, apparently for the first time, the theory that the defendant might have approached the victim to borrow money. Brief of Respondent, supra note 175 , at 39 n. 19 .

179. The district attorney made this argument to the trial court when he resisted deliberate-design and culpable-negligence manslaughter instructions. Although saying that neither of the instructions were supported by the evidence, the prosecutor actually argued that they required additional proof when he asserted, "We . . . couldn't prove simple murder if we wanted to. ... We don't have any intent. . . And ... the same thing would go for a manslaughter instruction . . . because if [someone kills during robbery it is capital murder] regardless of whether it's [done with criminal] negligence." Howell, 860 So. $2 \mathrm{~d}$ at 742-43 (quoting the district attorney's argument to the trial court).

180. The clearest statement of this argument was advanced in briefing before the Supreme Court. See Brief of Respondent, supra note 175, at 42 ("[Defendant] does not set forth any facts that would explain why the victim, who was minding his own business and running his paper route at 5:00 in the morning, would want to loan money to or buy drugs from [defendant]."). 
The state courts never distinguished between these two arguments. They lumped both together under the claim that murder and manslaughter instructions were not required "under the facts." 181

\section{Heads I Win, Tales You Lose: Prosecutorial and State Court Incentives} for Basing Denial of Lesser Included Offense Instructions on Lack of Evidence

In cases where prosecutors oppose lesser included offense instructions, they will generally favor the position that the instructions are unwarranted under the facts of the particular case rather than that the crime is not a lesser included offense as a matter of law. One reason for this preference lies in the consequences of the position for other cases. Prosecutors benefit from broad legal definitions of lesser included offenses in some cases, and they will, accordingly, prefer not to eliminate such benefits in future cases by securing a legal determination that one crime can never be a lesser included offense of another. ${ }^{182}$

A second reason for the prosecutorial preference lies in the beneficial standard of review accorded to trial court factual determinations. While appellate courts may defer to trial court characterizations of whether the record establishes a fact dispute requiring lesser included offense instructions, ${ }^{183}$ appellate courts must review a trial court's decision that one crime is not a lesser included crime of another as a matter of law.

The grounds for the state court's denial of the instructions may affect the outcome of a constitutional challenge. While Hopkins v. Reeves does not require jury instructions on noncapital crimes that are not lesser included

181. See supra text accompanying note 175 (quoting state supreme court opinion); Brief of Respondent supra note 175, at 31 ("There is nothing in [state] law that would have prevented ... the requested instructions, if they had been warranted by the evidence.") (emphasis added); id. at $39 \mathrm{n} .18$ (arguing defendant "failed to assert any facts or give any explanation as to how his actions in this case could possibly constitute depraved heart murder, either").

182. While the State of Mississippi relied on the position that capital murder had no applicable lesser included offenses in Howell, in other litigation the State was appealing from a determination that manslaughter was not a lesser included offense of murder, see State v. Shaw, 880 So. 2d 296, 304-05 (Miss. 2004) (holding in the State's unopposed appeal that the trial court erred in refusing to consider a manslaughter charge after dismissing the murder charge and opining that manslaughter was a lesser included offense of murder), and prosecutors likewise supported an amendment of Mississippi criminal laws that clarified that manslaughter is a lesser included offense both of murder and capital murder, Miss. Code ANN. § 99-19-5(1) (2000 \& Supp. 2004).

183. The failure of the state supreme court independently to evaluate the record indicates this is in effect what happened in Howell. See supra text accompanying note 181. Such a practice exists in tension with appellate rules that disfavor withholding lesser included offense instructions based on a weighing of the evidence. See supra notes 23-24. 
offenses as a matter of state law, ${ }^{184}$ Beck requires noncapital lesser included offense instructions when they are supported by the evidence. ${ }^{185}$

\section{Difficulty of Determining the Existence of a Factual Dispute}

The facts in Howell demonstrate the difficulty in determining whether a genuine evidentiary dispute exists that warrants lesser included offense instructions. It is not enough that the less serious crimes of simple murder and manslaughter are amply supported by evidence that the defendant shot the victim to death at close range through the heart. ${ }^{186}$ Lesser included offense instructions need not be given merely because there is sufficient evidence to convict; rather, the facts must show a real question as to the presence of the elements that distinguish the greater and lesser offense. ${ }^{187}$

In Howell the facts that distinguished the crime of capital felony murder from lesser homicides involved the attempt to commit robbery. Evidence for attempted robbery included: 1) defendant's financial needs, ${ }^{188} 2$ ) defendant's reference to the victim as an "easy lick," 189 3) an altercation between defendant and victim evidencing the victim's resistance, ${ }^{190}$ and 4) robbery proceeds scattered by the victim's body. ${ }^{191}$ Perhaps the most compelling evidence of robbery was the inference of that motive resulting from the absence of other reasonable explanations for the defendant's behavior.

To counter the theory of robbery, the defense argued that the defendant's incriminating statements and financial motives provided evidence of motive to commit some crime other than robbery, which the victim might have resisted. ${ }^{192}$ The defendant also argued that absence of intent to commit

184. See supra text accompanying notes $139-43$.

185. Beck v. Alabama, 447 U.S. 625, 627-29 (1980).

186. Though the State argued that the evidence would not support a conviction for simple murder because of the absence of evidence of premeditation, under state law deliberate design is satisfied by a spontaneously formed intent to kill. Moreover, because depraved heart subsumes intent, so, a fortiori, does it include culpable negligence. The state definition of lesser included offenses was in flux in 2003, see generally Hoffheimer, supra note 125, at 136-38, but the legislature removed any doubts by defining murder as a lesser included offense of capital murder and manslaughter as lesser included offenses of murder, § 97-3-19(3).

187. See supra text accompanying note 42 .

188. See Howell, 860 So. $2 \mathrm{~d}$ at 732-33.

189. See id. at 713.

190. See id. at 714 .

191. See id. at 739

192. Id. at 743-44. Defense counsel specifically identified the crime of attempting to sell the victim drugs. 
robbery was shown by evidence that the killer left the scene without completing the robbery.

Given the defendant's discredited alibi defense, the time of the killing, and the lack of any evidence of prior drug sales between the defendant and the victim, a rational factfinder could easily reject the defendant's proffered explanation as unbelievable. Nevertheless, the defendant had done more than merely rely on the prosecutor's burden of proving the elements of the charged offense. The record indicates that the defendant's theory of the case raised a factual dispute as to whether the killer was engaged in attempted robbery.

\section{Federalism Issues}

This part of the Article explores the potential conflict between the constitutional requirement of lesser included offense instruction in capital cases and the Supreme Court's deference to state rules defining lesser included offenses. It considers the policies behind different state evidentiary requirements for lesser included offenses and argues that a minimal federal standard regarding the quantum of evidence necessary for giving lesser included offense instructions will adequately protect Beck's goal of reducing wrongful convictions while preserving a range of state control over jury instructions. Such a standard will empower states to enforce legitimate interests against improper jury compromise while preventing them from evading Beck's requirement through pretextual findings that salutary instructions are not warranted by the facts.

\section{A. Jury Factfinding and the Burden of Establishing a Factual Dispute}

By drawing the jury's attention to the elements that distinguish greater and lesser offenses when those elements are in dispute, lesser included offense instructions require juries to decide critical contested facts. This promotes two constitutional values. First, it promotes Beck's goal of removing the allor-nothing pressure to convict of a capital crime. Second, it promotes the more general goal of leaving disputed facts to juries.

Due process requires "proof beyond a reasonable doubt of every fact necessary to constitute the crime." 193 Conviction of a lesser included offense constitutes a partial acquittal of the more serious crime charged in an indictment and can, accordingly, be viewed as a form of partial defense. The 
posture of lesser included offenses as partial defenses is revealed most obviously in the traditional language of voluntary manslaughter, where "provocation" is said to mitigate liability. ${ }^{194}$ In the course of the nineteenth century, many jurisdictions codified lesser included offenses as lower "degrees" of a common offense class. ${ }^{195}$

Although the Supreme Court has struggled with the problem of the appropriate burden of proof for defenses to criminal charges, ${ }^{196}$ the Court has forcefully reasserted that any disputed fact that increases the offense level for a crime must be established beyond a reasonable doubt. ${ }^{197}$ In the context of lesser included offenses, the Supreme Court's opinions mean the State must either prove all the elements of the lesser offense beyond a reasonable doubt, or the State must prove the elements of the charged offense beyond a reasonable doubt, and the defendant must persuade the jury to lower the offense level.

Regardless of how the state chooses to cast the burdens of proof, the Constitution requires that factual determinations must be made by a properly informed jury. Instructing juries on lesser included offenses promotes the

194. As a matter of theory, provocation mitigates liability by establishing the absence of the "malice aforethought" required for murder. See BLACKSTONE, supra note 39, at *191 (“So, also, if a man be greatly provoked, as by pulling his nose, or other great indignity, and immediately kills the aggressor, though this is not excusable se defendendo, since there is no absolute necessity for doing it to preserve himself, yet neither is it murder, for there is no previous malice, but it is manslaughter."). Dressler observes that provocation may also provide a defense to other crimes that require malice aforethought. DRESSLER, supra note 41, at 527. Absence of malice will establish a complete defense unless the actor's conduct establishes proof of the elements of some other criminal offense.

195. Hoffheimer, supra note 11, at 381-89.

196. While a state must prove the elements of an offense beyond a reasonable doubt, and the Court once held that this meant that a state could not require a defendant to prove heat of passion as a defense, Mullaney v. Wilbur, 421 U.S. 684 (1975), the unmistakable trend is for the Court to permit states to shift the burden of proof on defenses, partial defenses, and excusing circumstances. E.g., Martin v. Ohio, 480 U.S. 228 (1987) (holding no constitutional violation in a state law that required a defendant to prove selfdefense by a preponderance of evidence); Patterson v. New York, 432 U.S. 197 (1977) (holding no constitutional violation in a state law that required a defendant to establish extreme mental or emotional disturbance in order to reduce murder to manslaughter).

197. See Apprendi v. New Jersey, 530 U.S. 466 (2000) (discussing the history of the common law preference for jury factfinding and proof beyond a reasonable doubt and holding that state law permitting judicial enhancement of penalties violated the constitutional requirements of proof of motive beyond a reasonable doubt based on factfinding by the jury). The Court subsequently held that Apprendi invalidated procedures that authorized sentencing judges to impose longer sentences based on facts found by the judges but not the juries. United States v. Booker, 125 S. Ct. 738 (2005) (holding that the Federal Sentencing Guidelines violated the Sixth Amendment to the extent that they permitted a judge to impose a longer sentence based on judicial factfinding); Blakely v. Washington, 124 S. Ct. 2531 (2004) (holding that state practices that authorized a judge to imposea longer sentence based on judicial factfinding violated the Sixth Amendment). 
value of jury factfinding, and, where the facts are in dispute, it promotes accurate jury factfinding.

\section{B. Shared State and Federal Interests in Reducing Wrongful Convictions}

Beck's goal of reducing the risk of erroneous convictions by eliminating all-or-nothing jury decisions in capital cases is shared by virtually all states. This is demonstrated by the fact that the state ban on lesser included offense instructions in capital cases, which Beck held to be unconstitutional, was unique to that state. ${ }^{198}$ Indeed, the shared federal and state policy is so strong and so well established that a state law banning all lesser included offense instructions might be vulnerable to the challenge that it advances impermissible state objectives ${ }^{199}$ or is simply irrational and advances no state interest. $^{200}$

Four different policies explain trial court decisions not to give lesser included offense instructions in particular cases. First, a policy of respecting party control over litigation explains why courts would not give instructions when neither party requests them. ${ }^{201}$ Second, a policy of preventing wrongful convictions explains why courts would not give instructions for lesser crimes when their elements are not proven by evidence the state must introduce for the charged offense - that is, when the lesser offenses are not lesser included offenses. ${ }^{202}$ Third, a policy of requiring adequate notice and preventing prejudicial surprise would explain why courts might not submit lesser included offense instructions when an adverse party had not had an opportunity to develop a case on the lesser included offense. Fourth, a policy

198. Beck v. Alabama, 447 U.S. 625, 635 (1980) (“Alabama's failure to afford capital defendants the protection provided by lesser included offense instructions is unique in American criminal law.").

199. Although Alabama argued that its all-or-nothing choice was designed to reduce wrongful convictions, $i d$. at $641-43$, the State's 96 percent conviction rate under the policy supports the more reasonable inference that it preferred the all-or-nothing choice because it coerced capital convictions.

200. Nebraska's policy for denying lesser included offense instructions for capital and non-capital felony murder prosecutions was never explained. See supra text accompanying notes 135-38.

201. This promotes party autonomy and may promote improved factfinding to the extent the parties are motivated by that goal. It is controversial among scholars. See supra note 45 .

202. When state law does not recognize the lesser offense as a lesser included offense, the instruction is not constitutionally required even in a capital case. Hopkins v. Reeves, 524 U.S. 88, 90-91 (1998); see supra Part IV.

Although the Nebraska rule seemed to originate in part as a limit against unfairly surprising defendants, it was later justified by an analysis of the elements of felony murder and lesser homicide. See State v. Price, 562 N.W.2d 340, 346 (Neb. 1997) (emphasizing that unintentional homicide was not an included offense in felony murder because felony murder itself required no proof of intent other than culpability for the felony). 
against facilitating improper jury compromise would explain judicial reluctance to give lesser included offense instructions except in those cases where a real dispute over the elements that distinguish crimes would make it reasonable for the jury to convict of the lesser and acquit of the greater offense.

\section{Divisions among States Regarding Policies Limiting Jury Acquittals}

There are differences among the states and between the state and federal courts with respect to the evidence necessary for lesser included offense instructions. Although Beck acknowledged that states differ in their descriptions of the amount of evidence necessary to give rise to a right to lesser included offense instructions, ${ }^{203}$ the Court concluded that "they agree that [lesser included offense instructions] must be given when supported by the evidence." 204

The divergence among states requires closer consideration. A minority of states require lesser included offense instructions in all cases regardless of the evidence. ${ }^{205}$ The minority approach does not express local attitudes about the division of labor between the bench and the jury with respect to factfinding. Rather, it results from a considered policy of encouraging partial jury nullification. ${ }^{206}$ The Iowa Supreme Court made this policy preference

203. Beck, 447 U.S. at $636-37$ n. 12.

204. Id. (citing case authority from almost every state).

205. See State v. Wimberly, 498 So. 2d 929, 932 (Fla. 1986) (holding that a trial court must instruct on any lesser included offense regardless of the evidence); State v. Jeffries, 430 N.W.2d 728, 737 (Iowa 1988) ("[Iowa courts] shall automatically instruct on a lesser-included offense if the legal test is met...."); People v. Heflin, 456 N.W.2d 10, 15 (Mich. 1990) ("A Michigan defendant may request and receive necessarily included offense instructions without regard to the evidence ...."). See generally Dorean M. Koenig, The Many-Headed Hydra of Lesser Included Offenses: A Herculean Task for the Michigan Courts, 1 Det. C. Rev. 41 (1975); John F. Yetter, Truth in Jury Instructions: Reforming the Law of Lesser Included Offenses, 9 St. Thom As L. Rev. 603, 646-49 (1997) (discussing and criticizing the Florida practice).

206. The Pennsylvania Supreme Court explained its older state practice of permitting juries to convict of manslaughter absent any evidence of provocation as grounded in a policy of permitting juries to exercise sympathy. Commonwealth v. Schaller, 426 A.2d 1090, 1093 (Pa. 1981). This authority, and the rationale for it, has been significantly limited. Commonwealth v. Carter, 466 A.2d 1328, 1332 (Pa. 1983) ("[T]he vitality of the rationale that an instruction on the lesser-included offense always be given regardless of the evidence in support of the defense is disputable.").

In addition to partial nullification, the Iowa court identified an additional policy; it concluded that giving lesser included offense instructions regardless of the evidence was easier. Jeffries, 430 N.W.2d at 733-34. But the claim that the rule is easier to apply is open to question. There are many cases where it is uncertain whether a requested offense qualifies as a lesser included offense. In the majority of jurisdictions, a trial court may refuse such instructions on alternative grounds that the offense is not a lesser 
explicit when it contrasted the "jury function theory," which "recognizes that the jury may reject all or any part of the State's evidence, whether controverted or not," with the "court function theory," which expresses judicial hostility to compromise verdicts. ${ }^{207}$

The Florida Supreme Court similarly justified its practice of instructing on all lesser included offenses as a form of jury pardon: "The requirement that a trial judge must give a requested instruction on a necessarily included offense is bottomed upon a recognition of the jury's right to exercise its "pardon power."' 208 Justice Shaw, in dissenting from the Florida practice, observed that such de facto jury nullification does not promote accurate factfinding: "My disagreement with the majority opinion is that it sacrifices the truth-finding process on the altar of the 'jury pardon' by injecting unnecessary confusion into a criminal prosecution." ${ }^{209}$

Not all state courts clearly explain why they favor giving instructions on lesser included offenses to juries regardless of the evidence. ${ }^{210}$ Even in the minority jurisdictions, appellate courts do not always insist on the practice. In two states, appellate courts have not followed court rules that appear to mandate instructions regardless of the evidence. ${ }^{211}$ At least one state, after

included offense and that it is not warranted by the evidence.

207. $I d$.

208. Wimberly, 498 So. 2 d at 932 (quoting State v. Baker, 456 So. 2d 419, 422 (Fla. 1984)).

209. Id. (Shaw, J., dissenting).

210. In Michigan, the status of the practice and the reasons for adopting it are uncertain. The Michigan courts have repeatedly restated the rule that lesser included offense instructions must be given regardless of the evidence. Heflin, 456 N.W.2d at 15; see also People v. Veling, 504 N.W.2d 456, 462 (Mich. 1993). This is seemingly inconsistent with older authority that required lesser included offense instruction only where the defendant established a dispute on the element that distinguished the greater and lesser offenses. People v. Hamilton, 42 N.W. 1131, 1132 (Mich. 1889). The Michigan court justified its later policy as necessary to promote jury factfinding on all elements, citing California authority. See People v. Chamblis, 236 N.W.2d 473, 476-77 (Mich. 1975) (citing People v. St. Martin, 463 P.2d 390, 394 (Cal. 1970)). California, however, requires lesser included offense instructions only in cases where there is substantial evidence that the defendant is guilty only of the lesser and not of the greater offense. E.g., People v. Cole, 95 P.3d 811, 850 (Cal. 2004). Michigan's treatment of lesser included offenses is complicated by the fact that the State distinguished for some time between necessarily lesser included offenses and cognate lesser included offenses. With respect to the latter, the court recognized the need to restrict instruction in order to limit jury nullification. See People v. Hendricks, 521 N.W.2d 546, 552-53 (Mich. 1994) (discussing the problem of jury decision-making that is motivated by mercy).

211. See Tenn. Code Ann. § 40-18-110(a) (1997).

When requested by a party in writing prior to the trial judge's instructions to the jury in a criminal case, the trial judge shall instruct the jury as to the law of each offense specifically identified in the request that is the lesser included offense of the offense charged in the indictment or presentment. However, the trial judge shall not instruct the jury as to any such offense unless the judge determines that the record contains any evidence which reasonable minds could accept as to the lesser included offense. 
initially adopting such an approach, experienced judicial reluctance to follow it and eventually abandoned it. ${ }^{212}$

Partial jury nullification may promote local values of juror decisionmaking by expanding the jury's role to include discretionary acts of mercy. This practice is not required to preserve a defendant's right to trial by jury. ${ }^{213}$ Moreover, such broad discretionary power to acquit raises special problems in capital cases to which the Beck rule applies. Unguided jury discretion renders state capital punishment schemes unconstitutional. ${ }^{214}$ Instructing juries on noncapital lesser offenses that are not supported by the evidence would invite discretionary partial acquittals. ${ }^{215}$

The approach of the vast majority of states comports with the practice of federal courts where "the defendant is entitled to an instruction on a lesser included offense if the evidence would permit a jury rationally to find him guilty of the lesser offense and acquit him of the greater." ${ }^{216}$ Nor is the wide judicial consensus coincidental. Although the tests may be formulated in different terms ${ }^{217}$ they advance a common objective. The evidentiary

Id.; see also LA. Code Crim. Proc. AnN. art. 803 (2004) (appearing to mandate the instruction on lesser included offenses when requested). But see State v. Johnson, 823 So. 2d 917, 922 (La. 2002) (holding that the failure to instruct on a lesser included offense may be harmless error); State v. Langford, 994 S.W.2d 126, 128 (Tenn. 1999); State v. Stephenson, 878 S.W.2d 530, 550 (Tenn. 1994) (holding that it is not error to fail to give instructions where the record clearly establishes culpability of the greater offense and is devoid of evidence of the lesser included offense).

212. See Dean v. State, 77 P.3d 692, 697-98 (Wyo. 2003) (discussing the lack of consistency in Wyoming decisions under the "jury function theory" approach to lesser included offenses and returning to an approach that required instruction on a lesser included offense only when an evidentiary dispute made it rational for the jury to acquit of the greater offense and convict of the lesser offense).

213. The Supreme Court categorically rejected any right to instruction on lesser included offenses not supported by evidence. Sparf v. United States, 156 U.S. 51, 63-64 (1895).

214. Furman v. Georgia, 408 U.S. 238 (1972) (holding unconstitutional state procedures giving the jury unlimited discretion in deciding to impose capital punishment).

215. Justice Stewart objected to such a possibility in holding unconstitutional a Louisiana statute that mandated the death penalty for first-degree murder but that also required instruction on noncapital seconddegree murder and manslaughter regardless of the evidence. He observed that the "element of capriciousness in making jurors' power to avoid the death penalty [is] dependent on their willingness to accept this invitation to disregard the trial judge's instructions.” Roberts v. Louisiana, 428 U.S. 325, 335 (1976) (Stewart, J., joined by Powell \& Stevens, JJ.).

216. Beck v. Alabama, 447 U.S. 625, 635 (1980) (quoting Keeble v. United States, 412 U.S. 205, $208(1973))$.

217. E.g., New York requires a trial court to submit requested lesser included offense instructions "if there is a reasonable view of the evidence which would support a finding that the defendant committed such lesser offense but did not commit the greater," N.Y. Crim. Proc. LaW § 300.50(1) (McKinney Supp. 2005); California requires that there be "substantial evidence" to support a finding of guilt of the lesser offense and innocence of the greater offense, People v. Cole, 95 P.3d 81 1, 850 (Cal. 2004); Alaska requires "some evidence" of a dispute, Nathaniel v. State, 668 P.2d 851, 855 (Alaska Ct. App. 1983). Compare 
requirements reflect the policy that lesser included offense instructions should be given only where they aid the jury in determining the appropriate level of an offense when the elements that distinguish the greater and lesser offenses are genuinely disputed. Conversely, the reluctance to instruct regardless of an evidentiary dispute expresses the conviction that lesser included offense instructions can frustrate accurate factfinding by promoting improper jury compromise. ${ }^{218}$

Federal and state courts share the goal of avoiding the risk of wrongful capital convictions that result from all-or-nothing instructions. The majority of states also share the goal of reducing the risk of improper jury compromise in cases where there is no genuine factual dispute about the elements that distinguish the greater and lesser included offenses. These mutual and overlapping goals are fully effectuated by rules that withhold lesser included offense instructions in those cases where reasonable jurors could not acquit of the greater offense but could convict of the lesser included offense. This is the statement of the rule both in federal court and in many state cases. ${ }^{219}$

United States v. Kuefler, 14 C.M.A. 136, 139 (C.M.A. 1963) (observing that a lesser included offense instruction is required when "some evidence" supports it), with id. at 140 (Quinn, C.J., dissenting) (observing that a lesser included offense instruction is required when there is "sufficient credible evidence").

218. These policies are recognized, at least in part, by jurisdictions that espouse the rule that lesser included offense instructions be given regardless of the evidence. See State v. Barritt, 531 So. 2d 338 (Fla. 1988); Martin v. State, 342 So. 2d 501, 502 (Fla. 1977) (holding that lesser included offense non-homicide instructions are not required where the fact of death is not disputed).

219. Keeble, 412 U.S. at 208. The Keeble rule is cited with approval in a majority of states. See, e.g., Julius v. State, 455 So. 2d 975, 980 (Ala. Crim. App. 1983); Nathaniel, 668 P.2d at 855; People v. Hughes, 39 P.3d 432, 483 (Cal. 2002); State v. MacFarlane, 450 A.2d 374, 377 (Conn. 1982); Henry v. State, 805 A.2d 860, 864 n. 18 (Del. 2002); Moore v. United States, 599 A.2d 1381, 1383-84 (D.C. 1991); People v. Garcia, 721 N.E.2d 574, 584 (IIl. 1999); State v. Johnson, 823 So. 2d 917, 922 (La. 2002); Morse v. State, No. CV-79-184, 1979 Me. Super. LEXIS 102, at*4 n.3 (Me. Super. Ct. July 19, 1979); State v. Bowers, 709 A.2d 1255, 1259 (Md. 1998); Commonwealth v. Spear, 319 N.E.2d 455, 458 (Mass. App. Ct. 1974); State v. Tellinghuisen, No. C4-90-2464, 1991 Minn. App. LEXIS 409, at *8 (Minn. Ct. App. May 7 , 1991); Grace v. State, 375 So. 2d 419, 420 (Miss. 1979); State v. Kills on Top, 793 P.2d 1273, 1296 (Mont. 1990); State v. Bacon, 319 A.2d 636, 639 (N.H. 1974); State v. Saulnier, 306 A.2d 67, 70 (N.J. 1973); State v. Swafford, 782 P.2d 385, 389 (N.M. Ct. App. 1989); State v. King, 546 S.E.2d 575, 595 (N.C. 2001); State v. Keller, 695 N.W.2d 703, 707 (N.D. 2005); State v. Kidder, 513 N.E.2d 311, 314 (Ohio 1987); Frederick v. State, 37 P.3d 908, 944 (Okla. Crim. App. 2001); Commonwealth v. Wilds, 362 A.2d 273, 278 (Pa. Super. Ct. 1976); State v. Sullivan, 541 A.2d 450, 453 (R.I. 1988); State v. Kincaid, No. 03C01-9707-CR-00306, 1999 Tenn. Crim. App. LEXIS 959, at*13 (Tenn. Ct. App. Sept. 27, 1999); Baldree v. State, 784 S.W.2d 676, 687 (Tex. Crim. App. 1989); State v. Baker, 671 P.2d 152, 158 (Utah 1983); State v. Swift, 844 A.2d 802, 805 (Vt. 2004); State v. Carrington, 397 N.W.2d 484, 491 n.11 (Wis. 1986); Seeley v. State, 715 P.2d 232, 238 (Wyo. 1986); see also Commonwealth v. Kaipat, No. 94-052, 1995 N. Mar. I. LEXIS 6, at*8 (N. Mar. I. Oct. 23, 1995). Some jurisdictions that do not explicitly cite Keeble nevertheless adopt a virtually identical rule under local rules. See N.Y. Crim. Proc. Law 
Imposing such an evidentiary requirement for submission of lesser included offense instructions in capital cases under Beck would in no way prevent states from giving lesser included offense instructions that are supported by less evidence. But state trial court decisions withholding lesser included offense instructions, though arguably in violation of local rules, would not automatically offend a defendant's constitutional right to a fair trial. Any local policy preference for jury decision-making at the cost of erroneous factfinding is not compatible with Beck's objective of reducing jury error. ${ }^{220}$

A minimum independent evidentiary requirement for lesser offense instructions would assure that the constitutional interest in reducing erroneous factfinding in capital cases would not be evaded by states under the form of a nonreviewable determination that the evidence was not sufficient to require such instructions.

2. Accommodating Beck's Constitutional Policy of Reducing the Risk of Wrongful Capital Convictions with State Rules Designed to Prevent Improper Jury Compromise

There is some variation among jurisdictions that require evidence for lesser included offense instructions as to exactly what they require. These states must weigh the benefits of jury factfinding against the risks of improper compromise, and it is understandable that they might reach different judgments. Moreover, the legal consequences of giving lesser included offense instructions vary from state to state. For example, states differ in their treatment of convictions of lesser included offenses that are not supported by evidence when the evidence would have been sufficient to support a conviction of the greater offense. ${ }^{21}$ States that permit convictions of lesser

$\S 300.50$ (1) (McKinney Supp. 2005), quoted supra note 217.

220. Iowa and Florida justify their no-evidence rule as a form of preference for jury decision-making and even "jury pardon." State v. Wimberly, 498 So. 2d 929, 932 (Fla. 1986); State v. Jeffries, 430 N.W.2d 728, 737 (Iowa 1988).

221. Juries may compromise by convicting of a less serious offense that is not adequately supported by the evidence. Jurisdictions consistently applying the elements test will never define such lesser offenses as lesser included offenses. But, most jurisdictions recognize some lesser included offenses that require proof of different or additional facts from the greater offense. Such jurisdictions are split over how to treat convictions of lesser included offenses when the evidence is sufficient for the charged offense but not sufficient for the lesser offense - for example, where a defendant is charged with first-degree murder but convicted of voluntary manslaughter absent adequate proof of provocation. See Milton Roberts, Propriety of Manslaughter Conviction in Prosecution for Murder, Absent Proof of Necessary Elements of Manslaughter, 19 A.L.R. 4th 861 (2005).

The division of authority may express different judgments about the costs of correcting erroneous 
included offenses based on sufficient evidence of the greater offense even absent proof of special elements of the lesser offense have less incentive to restrict lesser included offense instructions.

But despite such local variations, the majority of states restrict lesser included offense instructions only to the extent necessary to avoid compromise verdicts that are unsupported by the record. This policy of avoiding erroneous factfinding comports with the constitutional requirement in Beck and Hopper that lesser included offense instructions must be given only when they are supported by evidence.

The Supreme Court has made clear that the evidence requirement serves an independent constitutional purpose. ${ }^{222}$ Even if state courts improperly deny lesser included offense instructions, the denial does not violate constitutional rights when there is no evidence requiring the instruction. ${ }^{223}$

Conversely, respect for state interests in controlling determinations regarding the quantum of evidence necessary for lesser included offense instructions ${ }^{224}$ would be incompatible with the purposes of Beck if state practices effectively eliminated the availability of lesser included offense instructions other than in those cases where the instructions aggravated the risk of erroneous jury factfinding.

The lack of identity between state and federal interests in controlling lesser included offense instructions is greatest in those states that require lesser included offense instructions in all cases. Because the Constitution requires such instructions only when warranted by the evidence, the violation of state law by a state court's failure to instruct would not establish a constitutional violation. But if a court in such a state refused to give lesser included offense instructions in a capital case, and if such instructions were necessary to resolve a factual dispute over the proof of the additional elements necessary to secure a conviction of the charged offense, then the failure to instruct would be unconstitutional.

The constitutional requirement of lesser included offense instructions is designed to reduce the risk of erroneous convictions in capital cases. Where there is no such unacceptable risk - for example, in a prosecution for first-

factfinding, but it may also embody different judgments about the essential fairness of convicting a defendant of the "wrong" crime based on sufficient evidence of guilt of a more serious crime.

222. See supra text accompanying note 89.

223. Hopper v. Evans, 456 U.S. 605 (1982) (affirming a capital conviction where lesser included offense instructions were unavailable pursuant to a state statute found unconstitutional in Beck, but where no evidence warranted the instruction).

224. For a forceful argument for such deference, see Brief Amicus Curiae of Criminal Justice Legal Foundation in Support of Respondent, Howell v. Mississippi, 125 S. Ct. 856 (2005) (No. 03-9560). 
degree murder where the jury rejects a defense of insanity - then the omission of lesser included offense instructions does not offend the constitutional principles recognized by Beck even if it violates state law. But a state rule imposing onerous evidentiary prerequisites for lesser included offense instructions, even if permissible in noncapital contexts, must yield to the constitutional interest in reducing erroneous factfinding in capital cases that results from forcing juries to make all-or-nothing decisions in the absence of lesser included offenses in cases where there is ample evidence of the lesser offense and a genuine dispute about the elements that distinguish the greater and lesser included offenses.

Practical considerations also counsel against a policy of wholesale deference to state rules regarding the evidence necessary for lesser included offense instructions. First, the state proceedings in Howell demonstrate how counsel and courts can easily reformulate the legal issue of whether a crime qualifies as a lesser included offense as a factual issue of whether the evidence is sufficient to warrant the lesser offense instruction. ${ }^{225}$

Finally, a policy of deference to state rules would not achieve the stated federalist goal of reducing federal judicial interference in state court decisions. On the contrary, a constitutional rule permitting states to avoid lesser included offense instructions would effect dramatic changes in current state law by encouraging states to adopt restrictive evidentiary requirements for lesser included offense instructions in capital cases.

\section{The Proposed Standard}

Some measure of review of trial decisions denying lesser included offense instructions is necessary to preserve Beck's core value, to provide a corrective against prosecutorial incentives to seek denial of instructions on evidentiary grounds, and to curb the practice evident in some state courts of providing only the most cursory justification for such denials. Beck's goals of reducing erroneous factfinding can be effectuated and a wide measure of state control over the regulation of lesser included offense instructions can be preserved by a minimal evidentiary requirement for lesser included offense instructions. 


\section{Independent Standard Governing When Lesser Included Offense Instructions Must Be Given}

The standard currently employed in federal trials is substantially similar to that followed by most states. The standard restricts the right to lesser included offense instructions to cases where there is not only evidence sufficient to support a conviction of the lesser included offense but where there is also a real dispute about the element that differentiates the greater and lesser included offenses.

In the language of Schmuck v. United States, ${ }^{226}$ "[T] he evidence at trial must be such that a jury could rationally find the defendant guilty of the lesser offense, yet acquit him of the greater."227 There must be a factual dispute on the element that distinguishes the greater and lesser offenses. ${ }^{228}$ The dispute must be established by something more than the prosecutorial burden of proof that applies to all elements (otherwise there would always be a factual dispute), and lesser included offense instructions are not required in federal trial practice when the inculpatory evidence applies equally to greater and lesser offenses. ${ }^{229}$

Accordingly, the federal standard does not require manslaughter instructions where a defendant is prosecuted for murder and the government's evidence of brutal, deliberate homicide is not met by any showing of provocation. ${ }^{230}$ Nor are defendants prosecuted for felonious tax evasion entitled to lesser included offense instructions on criminal offenses that also require proof of willful evasion. ${ }^{231}$ Chief Justice Burger effectively applied a nearly identical standard in Hopper v. Evans ${ }^{232}$ in holding (without reference

226. 489 U.S. 705, 716 (1989) (adopting the elements test as the definition of a lesser included offense in federal prosecutions).

227. Id. at 716 n. 8 (citing Keeble v. United States, 412 U.S. 205, 208 (1973)). The Keeble decision was cited and quoted at length in Beck v. Alabama, 447 U.S. 625, 634-35 (1980). Lower federal courts have repeatedly applied the test and clarified its application. United States v. Harrison, 55 F.3d 163, 166 (5th Cir. 1995); United States v. Deisch, 20 F.3d 139, 142 (5th Cir. 1994) (holding that a lesser included offense instruction must be given when 1) the crime meets the federal elements test and 2) "the evidence at trial permits a jury to rationally find the defendant guilty of the lesser offense yet acquit him of the greater").

228. Sansone v. United States, 380 U.S. 343, 350 (1965) (citing Berra v. United States, 351 U.S. 131 (1956); Sparf v. United States, 156 U.S. 51, $63-64$ (1895)).

229. Id. at 350 .

230. Sparf, 156 U.S. at 63-64.

231. Sansone, 380 U.S. at 350; Berra, 351 U.S. at 131-35.

232. 456 U.S. 605 (1982); see also supra notes 77-89 and accompanying text. 
to state law) that a defendant who confessed to deliberately killing a robbery victim was not entitled to lesser included offense instructions.

\section{Burdens on State and Federal Courts}

The Beck rule has not proved to be a burden on state procedure, ${ }^{233}$ and a minimal evidentiary standard for lesser included offense instructions would impose no additional burden on state courts because states already engage in evidentiary determinations prior to giving lesser included offense instructions. ${ }^{234}$ While the minimal standard would prevent states from pretextual denials of lesser included offense instructions and would also prevent state judges from radically altering lesser included offense rules in the form of rules of evidence, the standard would not interfere with the diverse practice of states that apply lower evidentiary standards designed to implement valid state policies. (It would not, however, constitutionalize violations of such lower standards.)

Neither would a minimal evidentiary standard place a burden on federal courts. Beck already restricts the constitutional right to lesser included offense instructions to capital cases. ${ }^{235}$ The opportunity for federal court review has been reduced by limits on access to habeas corpus relief, ${ }^{236}$ and the

233. Barta maintains that even the more expansive standard rejected in Hopkins v. Reeves, 524 U.S. 88 (1998), would not have placed a burden on state capital litigation. Barta, supra note 122, at 1462 (noting that the rule rejected by the Court in Hopkins "does not represent a significant threat to state autonomy. Nebraska remained free to impose the death penalty pursuant to a felony murder conviction. It was simply prohibited from imposing the death penalty under a scheme which forced a jury to choose between conviction on a capital offense and outright acquittal.").

234. An independent evidentiary requirement may in fact protect state decisions from reversal. See Hopper, 456 U.S. at 609-12 (holding that a state's refusal to give lesser included offense instructions was not unconstitutional where the instructions were not supported by evidence even though the State's refusal to give instructions was pursuant to an unconstitutional statute).

235. Shellenberger and Strazzella argue that limiting the right to capital cases was necessary to prevent federal courts from being flooded with constitutional challenges to routine state court decisions denying lesser included offense instructions. Shellenberger \& Strazzella, supra note 17, at 18 ("The pervasive nature of the [lesser included offense] doctrine and the vast number of state criminal cases suggest that broadly constitutionalizing [the requirement of instruction on lesser included offenses] would overwhelm the federal courts and involve those courts in state criminal law issues to an unmanageable and undesirable extent."). The authors suggest that pragmatic concerns about limiting federal collateral review of state proceedings has affected other aspects of the Court's treatment of lesser included offenses. $I d$. at 91-92.

236. See generally Antiterrorism and Effective Death Penalty Act of 1996, 28 U.S.C. $§ 2244$ (2000) (barring relitigation of claims that have been presented or could have been presented in previous applications for relief); ER WIN CHEMERINSKY, FEDERAL JURISDICTION 871-72 (4th ed. 2003) (discussing the restriction of habeas corpus review under the Burger and Rehnquist Courts). 
possibility of Supreme Court review is reduced by the Court's new requirement that the federal constitutional authority for any Beck violation must be presented unequivocally to the state courts. ${ }^{237}$

\section{CONCLUSion}

The future of constitutionally required lesser included offense instructions hangs in the balance. On one side, Beck's constitutional commitment to eliminating the all-or-nothing pressure to convict in capital cases requires meaningful limits on state courts' refusals to give lesser included offense instructions. On the other side, federalist policies lead the Supreme Court to defer to state rules governing such instructions.

This Article contends that federalist arguments ignore the shared federal and state interests in preventing wrongful convictions, overstate state interests in autonomy and exaggerate the extent to which a uniform requirement would interfere with state criminal procedure. Accordingly, it proposes that to preserve the core benefits of Beck, the Supreme Court should adopt an independent evidentiary standard and require lesser included offense instructions in all capital cases where a reasonable jury could find the defendant not guilty of the charged offense but guilty of the lesser included offense. This proposal is consistent with existing case law, would be easy to apply and would interfere with state criminal procedure only to the extent necessary to achieve Beck's goal of reducing wrongful capital convictions. 